\title{
Importance and nutritional value of large ciliates for the reproduction of Acartia clausi during the post spring-bloom period in the North Sea
}

\author{
Jörg Dutz ${ }^{1,3, *}$, Janna Peters ${ }^{2}$ \\ ${ }^{1}$ Department of Biological Oceanography, Institute for Baltic Sea Research Warnemünde, Seestraße 15, 18119 Rostock, Germany \\ ${ }^{2}$ Department of Marine Zoology, University of Bremen, PO Box 330440, 28334 Bremen, Germany \\ ${ }^{3}$ Present address: Department of Marine Ecology and Aquaculture, Danish Institute for Fisheries Research, Kavalergården 6, \\ 2920 Charlottenlund, Denmark
}

\begin{abstract}
Shipboard experiments were performed to examine the qualitative importance of large marine microzooplankton for the reproduction of Acartia clausi in the North Sea. Feeding and egg production were compared in 2 treatments in which females were fed natural seston or natural seston selectively enriched with large prey $(>20 \mu \mathrm{m})$. The mineral $(\mathrm{C}, \mathrm{N})$ and lipid contents of the food suspensions were determined for size-fractionated samples to characterize the nutritional composition of prey. Large oligotrich ciliates and Strobiliidae dominated the seston biomass. Ciliates, particularly the oligotrich Laboea strobila, were the preferred food and made up more than $86 \%$ of the diet $\left(2.9 \mu \mathrm{g} \mathrm{C}\right.$ female $\left.\mathrm{e}^{-1} \mathrm{~d}^{-1}\right)$ in the natural treatment. Small thecate dinoflagellates composed the remaining part. Egg production was high ( $>25$ eggs female $\left.{ }^{-1} \mathrm{~d}^{-1}\right)$, achieving maximum rates recorded for this species in the North Sea. Ingestion and egg production of females increased equally in the enriched treatment, largely due to ingestion of additional ciliates. This allowed calculation of the gross growth efficiency for egg production on a diet of mixed ciliates, which was high at $\sim 30 \%$. Measurements of the mineral and lipid content confirmed a high seston nutritional quality. The 20 to $48 \mu \mathrm{m}$ fraction reflected the composition of female diets and indicated an enrichment of $\mathrm{N}$ and polyunsaturated fatty acids (PUFA) in the diet compared to total seston. The fraction $>48 \mu \mathrm{m}$ consisted mostly of ciliates ( $>97 \%$ ) and was particularly important in providing $\mathrm{N}$ to copepods. Ciliates were also rich in PUFA and eicosapentaenoic acid (EPA), which is normally characteristic of diatoms. We conclude that large ciliates constitute an excellent food source for the reproduction of A. clausi. The occurrence of biomass peaks of large ciliates following the spring diatom bloom probably contributes substantially to the spring recruitment of the species in the North Sea.
\end{abstract}

KEY WORDS: Acartia clausi $\cdot$ Feeding $\cdot$ Egg production $\cdot$ Ciliates $\cdot$ Laboea strobila $\cdot$ Biochemical composition $\cdot$ Polyunsaturated fatty acids $\cdot$ North Sea

\section{INTRODUCTION}

Large hetero- or mixotrophic protists are an important component in the diet of marine pelagic copepods. Stimulated by early descriptions of copepod grazing on ciliates (Berk et al. 1977, Turner \& Anderson 1983), numerous studies found ciliates and heterotrophic dinoflagellates to be a significant and often preferentially consumed prey in subtropical (Gifford \& Dagg
1991, Broglio et al. 2004, Liu et al. 2005), temperate (Tiselius 1989, Fessenden \& Cowles 1994) and polar ecosystems (Gifford \& Dagg 1991, Levinsen et al. 2000). Since these protists are major consumers of the pico- and nanoplankton production that is unavailable to large crustacean zooplankton, dietary preference forms an important link between microbial food webs and the classical food chain (Sherr \& Sherr 1988). Recent estimates indicate that on a global scale, the 
consumption of ciliates alone amounts to $>1 / 3$ of the C flux processed by zooplankton grazing on phytoplankton (Calbet \& Saiz 2005). A high grazing pressure on ciliates can also temporarily control their production and have a strong influence on the composition of the microbial food web (Nielsen \& Kiørboe 1994, Merrell \& Stoecker 1998).

Besides the structural and functional importance of zooplankton feeding on microzooplankton in food webs, comparatively little is known about its contribution to pelagic secondary production. Microzooplankton is generally considered to be food of excellent quality that provides high levels of nitrogen or essential lipids to pelagic omnivores (Stoecker \& Capuzzo 1990, Sanders \& Wickham 1993, Klein Breteler et al. 1999). This is supported by studies showing that ciliates and heterotrophic dinoflagellates substantially enhance growth, egg production and survival of copepods in the laboratory (Berk et al. 1977, Stoecker \& Egloff 1987, Klein Breteler et al. 1999). Recent studies also demonstrate that microzooplankton can improve the quality of nutritionally poor food and provide essential fatty acids or sterols for growth and egg production (Klein Breteler et al. 1999, Broglio et al. 2003, Tang \& Taal 2005). However, the ability to upgrade the nutritional quality by de novo synthesis or modification of algal lipids is apparently limited to heterotrophic dinoflagellates. Ciliates, in contrast, reflect primarily the lipid composition of their food (Ederington et al. 1995, Broglio et al. 2003, Klein Breteler et al. 2004). This suggests that the nutritional quality of ciliates in the field is largely dependent on the variable composition and growth conditions of their food.

Despite recent progress in the characterization of microzooplankton quality in the laboratory, information on the nutritional composition and the importance of ciliates for production in the field is scarce. Microzooplankton is a major source of the mineral and biochemical composition of seston following the spring bloom in the temperate coastal ocean (Mayzaud et al. 1989, Pond et al. 1996), and feeding on heterotrophic protists may account for the apparent failure of phytoplankton ingestion to cover the energy demands of copepod egg production (Dam et al. 1994, Ohman \& Runge 1994). Field studies also found correlations between copepod egg production and microzooplankton abundance (White \& Roman 1992, Pond et al. 1996). However, due to generally low standing stocks of microzooplankton compared to the temporarily high phytoplankton biomass, feeding on heterotrophic protists has been suggested to contribute only a small fraction to the integrated annual production of copepods (Kiørboe \& Nielsen 1994).

Estimates of the role of microzooplankton in-and their nutritional value for - the production of copepods in the field are often confounded by a high diversity of potential food particles and of copepod diets. In order to determine the biochemical composition of microzooplankton and its utilization by copepods, we took advantage of the typical size structure of pelagic food webs following the spring bloom. While the plankton community at this time often consists of smaller phytoplankton and larger hetero- or mixotrophic protists, copepods often display a typical size-based preference for larger prey (e.g. Rollwagen-Bollens \& Penry 2003, Katechakis et al. 2004). Hence, we hypothesized that selective enrichment of large prey in the seston results in a simultaneous increase of its proportion in the diet and allows the characterization of its value for the reproduction of copepods. We used this approach during a cruise in the North Sea to determine (1) the contribution of microzooplankton to the diet and to the daily ration of Acartia clausi, (2) the efficiency with which these food items are converted into egg production, and (3) the mineral and biochemical composition of microzooplankton. Grazing and egg production of female A. clausi were compared in 2 treatments: one group received natural seston as food while the second group was fed natural seston in which large organisms were selectively enriched. Both food suspensions were analyzed for lipid composition and $\mathrm{C}$ and $\mathrm{N}$ contents in order to characterize their nutritional value.

\section{MATERIALS AND METHODS}

Study site. The investigation was performed onboard RV 'Heincke' (Alfred Wegener Institute, Germany) during a cruise in the North Sea from May 17 to 28,2005 . Experiments were carried out over a period of 4 consecutive days during which a central station located in the German Bight (southern North Sea, $54^{\circ} 7.8^{\prime} \mathrm{N}, 7^{\circ} 15.0^{\prime} \mathrm{E}$; $38 \mathrm{~m}$ depth) was visited daily.

Sample collection. Each day, 80 to $100 \mathrm{l}$ water samples were taken with a rosette at depths of 5 to $10 \mathrm{~m}$. The water was carefully siphoned into $25 \mathrm{l}$ carboys, avoiding air bubbling. Zooplankton grazers were removed by filtering through a large, submerged sieve (diameter $20 \mathrm{~cm}$, mesh size $100 \mu \mathrm{m}$ ). The carboys were immediately stored at in situ temperature $\left(\sim 10^{\circ} \mathrm{C}\right)$ under dim light conditions. One batch of seawater remained unchanged (hereafter referred to as the natural treatment), while in a second batch of seawater large protists were concentrated by a factor of 4 by slow, inverse filtration via a submerged $20 \mu \mathrm{m}$ sieve (referred to as the enriched treatment). Disruption by siphoning and sieving can cause considerable loss of ciliates (Gifford 1985). Both batches of seawater were therefore allowed to stabilize for $4 \mathrm{~h}$ before use in experiments or subsampling for mineral and biochem- 
ical contents to avoid the inclusion of damaged organisms. Copepods were collected with a WP-2 net (100 $\mu \mathrm{m}$ mesh size) equipped with a closed cod end and towed vertically from a depth of $20 \mathrm{~m}$ to the surface. The catch was transferred into buckets filled with surface sea water and brought into a temperaturecontrolled walk-in chamber set to ambient surface water temperatures.

Experiments. Two sets of experiments were conducted in parallel and structured as follows: In the first set of experiments ('manipulation experiments', Fig. 1), grazing and egg production of Acartia clausi were compared in the natural and in the enriched food treatments. Females for these experiments were picked from an initial catch and transferred each day to new, freshly prepared food suspensions for a period of $4 \mathrm{~d}$. On the 1st day of incubation, grazing of females was determined, followed by 2 more days for further adaptation to the experimental conditions before egg production of females was determined on the 4th day. Samples to characterize the quality of the food suspensions (lipid composition; C-, N-content) were taken on Days 1 (total seston) and 3 (size-fractionated seston), whereas samples for the analysis of protist species composition were taken each day during the incubation (Fig. 1). In the second set of experiments, in-situ egg production of freshly caught females was determined during each of Days 1 to 3 (Fig. 1). These experiments served as a control to evaluate how well egg production of females incubated in the natural treatment of the manipulation experiment reflects in-situ estimates.

Comparison of grazing and egg production in natural and enriched treatments: For each grazing treatment, 9 polycarbonate screw-cap bottles $(550 \mathrm{ml})$ were filled with the respective seawater. Duplicate $200 \mathrm{ml}$ samples from 3 bottles were taken immediately and fixed in $2 \%$ acidic Lugol's iodine for enumeration of the initial phytoplankton and microzooplankton composition. Three experimental bottles received 7 females each, while the remaining 3 bottles were run as controls without copepods. The bottles were incubated on a rotating plankton wheel $(0.3 \mathrm{rpm})$ submerged in a temperature-controlled water bath at in-situ temperature $\left(10^{\circ} \mathrm{C}\right)$ and dim light conditions (L:D 16:8). After $24 \mathrm{~h}$, the contents of the bottles were carefully emptied into a large beaker containing an inner compartment with $200 \mu \mathrm{m}$ mesh, which was slowly lifted to collect the females. Samples for the final phytoplankton and microzooplankton counts were immediately taken as described above. The females were transferred each day into fresh food suspensions during the following $2 \mathrm{~d}$ for further acclimation to food conditions. On the 4 th day, females were incubated in spawning chambers as described for the estimates of in-situ egg production rates (see next section). After an additional $24 \mathrm{~h}$, females were removed and eggs were concentrated on a submerged $20 \mu \mathrm{m}$ sieve. Eggs were counted under a dissecting microscope $(60 \times)$ and transferred to $250 \mathrm{ml}$ glass bottles containing GF/F filtered seawater for subsequent determination of hatching success. After incubation of eggs for $5 \mathrm{~d}$ at in-situ temperature, bottle contents were concentrated and remaining eggs, empty egg shells and hatched nauplii were counted. The condition of females was inspected visually under the binocular microscope during the daily transfer of individuals. Mortality of females in the experiment was $<7 \%$; dead females were not substituted. The prosome length of all females (PL) was measured under a dissecting microscope at the end of the experiment. The $\mathrm{C}$ weight of females was calculated from the relation $\log C=$ $-8.51+3.08 \log P L$ established by Uye (1982). Egg

$\begin{array}{cccr}\frac{\text { Manipulation experiments }}{\text { 'natural' }} & \text { 'enriched' } & \frac{\text { In-situ egg production }}{\text { 'natural' }} & \text { Food quality measurements } \\ <100 \mu \mathrm{m} & 4 \times 20-100 \mu \mathrm{m} & <100 \mu \mathrm{m}\end{array}$
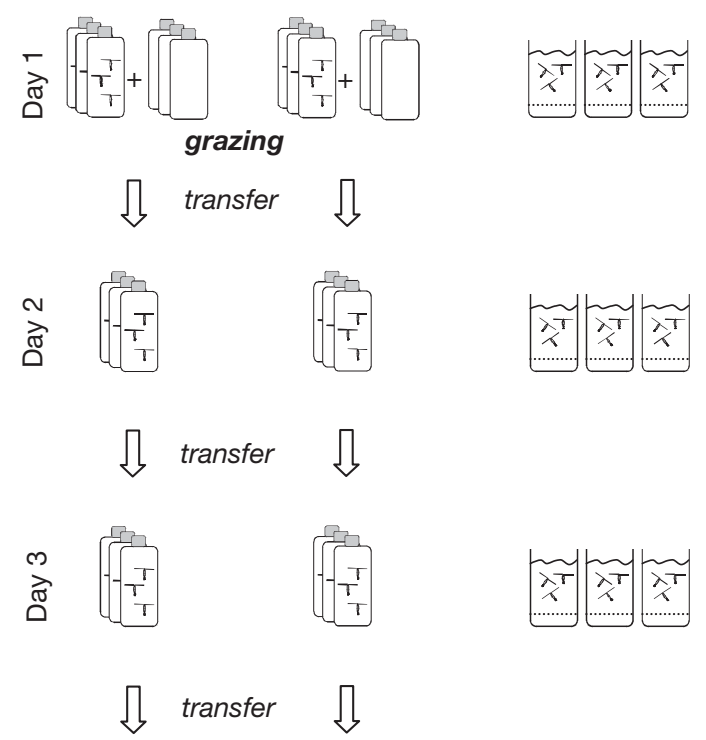

natural + enriched species composition

$\mathrm{C}$ and $\mathrm{N}$ content fatty acid composition

natural + enriched species composition

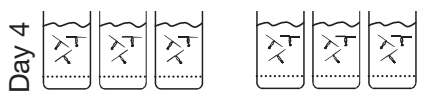

egg production
Fig. 1. Schematic description of manipulation experiments, in-situ egg production experiments and sampling for mineral and biochemical content of food suspensions 
volume was determined from the measurement of the diameter of at least 30 eggs per treatment and egg carbon was estimated by applying a conversion factor of $1.4 \times 10^{-6} \mu \mathrm{g} \mathrm{C} \mu \mathrm{m}^{-3}$ (Kiørboe et al. 1985).

Estimates of in-situ egg production: In-situ egg production of Acartia clausi was determined at Days 1 to 3, parallel to the manipulation experiment. Each day, freshly collected females were incubated in triplicate groups of 10 ind. in 11 spawning chambers, each containing an inner compartment with a bottom made of $100 \mu \mathrm{m}$ mesh gauze to prevent copepods from feeding on their eggs. The chambers were filled with in-situ seawater filtered through a $48 \mu \mathrm{m}$ sieve to remove any eggs. After $24 \mathrm{~h}$, females were removed, eggs were counted and egg hatching success was determined similar to the procedure described in the manipulation experiments.

Seston biochemical and mineral composition: With the onset of the feeding experiment, duplicate samples

Table 1. Taxonomic and size composition of seston biomass and respective contribution (\%) to total protist carbon, particulate organic carbon (POC) and nitrogen (PON), and $\mathrm{C} / \mathrm{N}$ ratio of food suspensions used in feeding experiments at Day 1. Numbers in parentheses denote prey categories; Category (17) 'others' refers to unidentified taxonomic groups

\begin{tabular}{|c|c|c|c|c|c|}
\hline & \multicolumn{2}{|c|}{ Natural treatment } & \multicolumn{2}{|c|}{ Enriched treatment } \\
\hline & & $\mu \mathrm{gCl}^{-1} \pm \mathrm{SD}$ & $\%$ & $\mu \mathrm{g} \mathrm{C} 1^{-1} \pm \mathrm{SD}$ & $\%$ \\
\hline \multicolumn{6}{|c|}{ Flagellates } \\
\hline & $<10 \mu \mathrm{m}$ & $4.8 \pm 0.21$ & 2.9 & $4.7 \pm 1.05$ & 1.1 \\
\hline & $<20 \mu \mathrm{m}$ & $0.4 \pm 0.04$ & 0.2 & $0.6 \pm 0.08$ & 0.1 \\
\hline & $<30 \mu \mathrm{m}$ & $0.1 \pm 0.02$ & 0.1 & $0.3 \pm 0.07$ & 0.1 \\
\hline \multicolumn{6}{|c|}{ Dinoflagellates } \\
\hline & Athecate $<20 \mu \mathrm{m}$ & $1.0 \pm 0.15$ & 0.6 & $2.3 \pm 0.29$ & 0.6 \\
\hline & Thecate $<20 \mu \mathrm{m}$ & $34.7 \pm 4.03$ & 21.4 & $90.5 \pm 5.44$ & 21.7 \\
\hline & Athecate $<30 \mu \mathrm{m}$ & $0.6 \pm 0.35$ & 0.4 & $1.9 \pm 0.04$ & 0.5 \\
\hline & Thecate $<30 \mu \mathrm{m}$ & $1.7 \pm 0.62$ & 1.1 & $12.0 \pm 3.31$ & 2.9 \\
\hline & Athecate $>30 \mu \mathrm{m}$ & $8.6 \pm 0.56$ & 5.3 & $15.4 \pm 3.49$ & 3.7 \\
\hline & Thecate $>30 \mu \mathrm{m}$ & $1.9 \pm 0.32$ & 1.2 & $6.0 \pm 0.40$ & 1.4 \\
\hline \multicolumn{6}{|c|}{ Diatoms } \\
\hline (10) & $<20 \mu \mathrm{m}$ & $0.1 \pm 0.01$ & 0.1 & $0.3 \pm 0.02$ & 0.1 \\
\hline (11) & $>30 \mu \mathrm{m}$ & $0.8 \pm 0.65$ & 0.5 & $1.6 \pm 0.32$ & 0.4 \\
\hline \multicolumn{6}{|c|}{ Ciliates } \\
\hline (12) & $<20 \mu \mathrm{m}$ & $0.2 \pm 0.04$ & 0.1 & $0.3 \pm 0.02$ & 0.1 \\
\hline & $<30 \mu \mathrm{m}$ & $0.8 \pm 0.06$ & 0.5 & $1.6 \pm 0.12$ & 0.4 \\
\hline & Laboea strobila $>30 \mu \mathrm{m}$ & $48.3 \pm 2.45$ & 29.8 & $121.6 \pm 10.46$ & 29.5 \\
\hline (15) & Strobiliidae $>30 \mu \mathrm{m}$ & $54.7 \pm 1.96$ & 33.8 & $152.7 \pm 27.90$ & 36.6 \\
\hline (16) & Others $>30 \mu \mathrm{m}$ & $0.9 \pm 0.25$ & 0.6 & $1.5 \pm 0.06$ & 0.4 \\
\hline \multicolumn{6}{|c|}{ Others } \\
\hline (17) & & $2.5 \pm 0.79$ & 1.5 & $3.5 \pm 0.58$ & 0.8 \\
\hline \multicolumn{6}{|c|}{ Size classes $(\mu \mathrm{m})$} \\
\hline $5-1$ & & $4.8 \pm 0.21$ & 3.0 & $4.7 \pm 1.05$ & 1.1 \\
\hline $10-$ & & $37.3 \pm 4.54$ & 23.0 & $95.6 \pm 5.31$ & 23.0 \\
\hline $20-$ & & $3.3 \pm 1.02$ & 2.0 & $15.9 \pm 3.54$ & 3.8 \\
\hline$>30$ & & $116.6 \pm 5.32$ & 72.0 & $300.7 \pm 35.46$ & 72.1 \\
\hline Tota & l protist carbon & $162 \pm 11.1$ & 100.0 & $417 \pm 35.9$ & 100.0 \\
\hline $\mathrm{POC}$ & $C\left(\mu g \mathrm{Cl}^{-1}\right)$ & 524 & & 743 & \\
\hline PON & $\mathrm{N}\left(\mu \mathrm{g} \mathrm{N} \mathrm{l^{-1 }}\right)$ & 96 & & 129 & \\
\hline $\mathrm{C} / \mathrm{N}$ & (weight) & 5.5 & & 5.8 & \\
\hline
\end{tabular}

for the determination of fatty acid, C and N concentration from the natural and enriched treatments were taken (Fig. 1). Approximately 500 to $1000 \mathrm{ml}$ of seawater was gravity filtered onto pre-combusted $\mathrm{GF} / \mathrm{C}$ filters $\left(24 \mathrm{~h}, 500^{\circ} \mathrm{C}\right)$ which were immediately frozen at $-80^{\circ} \mathrm{C}$ until analysis. On Day 3 of the incubation, samples for food quality measurements were taken from different size fractions $(<20 \mu \mathrm{m}, 20$ to $48 \mu \mathrm{m}, 48$ to $100 \mu \mathrm{m})$ to separate distinct components of the food suspension (e.g. small phytoplankton, large heterotrophic protists) and to characterize their contribution to overall food quality. Because the natural treatment was expected to provide sufficient material only for the biochemical characterization of small protists, it was sieved into fractions of $<20$ and $<48 \mu \mathrm{m}$. Samples for the measurement of larger but less abundant protists were prepared from the enriched treatment by sieving the seawater into size fractions of $<48$ and $<100 \mu \mathrm{m}$. The biochemical and mineral composition of the 20 to $48 \mu \mathrm{m}$ and the 48 to $100 \mu \mathrm{m}$ fractions were then obtained by subtraction of the respective smaller size fraction from the larger one. Samples were also preserved with $2 \%$ acidic Lugol's iodine for enumeration of the protist concentration in the natural and enriched treatments on Days 1 to 3 and in the different size fractions on Day 3.

Laboratory analysis. Microscopic enumeration of seston samples was done by the Utermöhl technique (Utermöhl 1958). Samples were concentrated by settling 10 to $100 \mathrm{ml}$ of seawater and examined under phase contrast optics (Zeiss Axiovert S 100). With the exception of flagellates $<10 \mu \mathrm{m}$ which were counted in stripes, organisms were enumerated by examining the entire chamber bottom at 200 or $400 \times$ magnification. Organisms were classified into different taxonomic categories and size classes (5 to 10,10 to 20,20 to 30 and $>30 \mu \mathrm{m}$, Table 1). The trophic status of ciliates and dinoflagellates was not examined as Lugol's iodine obscures chloroplasts. Protists which could not be identified were grouped in the category 'others'. This resulted in average counts $( \pm \mathrm{SD})$ of $602 \pm 77$, $1729 \pm 116,62 \pm 24$ and $415 \pm 119$ cells for flagellates, dinoflagellates, diatoms and ciliates, respectively. The average counts for the size classes were $449 \pm 59,1574 \pm 88$, $174 \pm 32$ and $699 \pm 173$ cells for $<10,10$ to 20,20 to 30 and $>30 \mu \mathrm{m}$, respectively. The cell volume of 30 to 40 cells of each taxonomic and size category was estimated from measurements of cell dimensions 
using a digital camera, an image analysis system (Olympus DP12, DP-Soft software) and formulas for appropriate geometric shapes. Biomass was calculated from established carbon to volume relationships for flagellates (Montagnes et al. 1994), dinoflagellates and diatoms (Menden-Deuer \& Lessard 2000) and ciliates (Putt \& Stoecker 1989). Filtration and ingestion rates of copepods were calculated in accordance with Frost (1972). The analysis of prey preferences of Acartia clausi were performed according to Chesson $(1978,1983)$. The selection index $\alpha$ of Chesson compares the proportion of each food species in the diet to its proportion in the seston (in terms of carbon); Selection is positive when $\alpha>$ $\mathrm{m}^{-1}$, where $\mathrm{m}$ is the number of food species. In the present study, $\alpha>0.06$ (17 groups of food items) indicates positive selection.

Fatty acid and $\mathbf{C} / \mathbf{N}$ analysis. Lipid extraction was performed with minor modifications as described in Folch et al. (1957) using ultrasonic disruption in dichloromethane:methanol (v/v:2/1) and a washing procedure with aqueous $\mathrm{KCl}$ solution $(0.88 \%)$. For quantification of fatty acids, tricosanoic acid was added as an internal standard prior to extraction. An additional centrifugation step was carried out prior to the washing procedure to remove GF/C filter remains. For fatty acid analyses, subsamples of total lipids were hydrolyzed and fatty acids were converted to their methyl ester derivatives (FAMEs) in methanol containing $3 \%$ concentrated sulphuric acid at $80^{\circ} \mathrm{C}$ for $4 \mathrm{~h}$ (Kattner \& Fricke 1986). After cooling, $2 \mathrm{ml}$ of distilled water were added, and FAMEs were extracted 3 times with $1 \mathrm{ml}$ hexane. Samples were analyzed using a gas chromatograph (HP 6890A) equipped with a DB-FFAP column (30 m length, $0.25 \mathrm{~mm}$ inner diameter, $0.25 \mu \mathrm{m}$ film thickness) operated with a temperature programme and helium as carrier gas. Samples were injected using a programmable temperature vaporizer injector (solvent vent mode). FAMEs and free fatty alcohols were detected by flame ionization and identified by comparing retention times with those derived from standards of known composition. $\mathrm{C}$ and $\mathrm{N}$ analyses were conducted using a Euro EA (HEKAtech) element analyser.

Statistical analyses. Clearance rates on different taxonomic groups or size classes in each treatment were compared by a Kruskal-Wallis test and nonparametric multiple comparisons by step (Sokal \& Rohlf 1995). A 1-way ANOVA was used to test for differences between diets in egg production and hatching, after testing for normality and homogeneity of variances. When applicable, Tukey's HSD test was run for multiple pairwise comparisons. A 2-sample $t$-test was used to compare differences in egg diameter between treatments. A 1-sample $t$-test was used to formally test the significance of positive or negative selection $(\alpha \neq$ 0.06, Sokal \& Rohlf 1995).

\section{RESULTS}

\section{Composition of the seston}

The biomass of the micro- and nanoplankton in the natural treatment was dominated by organisms in the size range of 10 to $20 \mu \mathrm{m}$ and $>30 \mu \mathrm{m}$ with an average of $37.3 \pm 4.54$ and $116.6 \pm 5.32 \mu \mathrm{g} \mathrm{C} \mathrm{l^{-1 }}$, respectively, for Day 1 of the experiment (Table 1). The bimodal size distribution largely reflected the taxonomic composition of the plankton. Thecate dinoflagellates $<20 \mu \mathrm{m}$ were responsible for the biomass peak in the 10 to $20 \mu \mathrm{m}$ size range and contributed an average of $34.7 \pm$

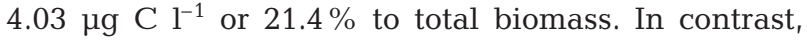
large ciliates caused the biomass maximum observed in the seston $>30 \mu \mathrm{m}$ and contributed $>60 \%$ to total biomass. They were dominated by a single oligotrich species, Laboea strobila (average size 82 x $58 \mu \mathrm{m}$, $48.3 \mu \mathrm{g} \mathrm{C} \mathrm{l}^{-1}$ ), and various large Strobiliidae (cf. Strobilidium spiralis, Strobilidium spp., average size $87 \mu \mathrm{m}$, $54.7 \mu \mathrm{g} \mathrm{C}^{-1}$ ). The biomass of other groups such as diatoms and flagellates was low.

In the enriched treatment, total protist $\mathrm{C}$ was increased by a factor of 2.6 to $417 \pm 35.9 \mu \mathrm{g} \mathrm{C} \mathrm{l}^{-1}$ in comparison to the natural treatment $(162 \pm 11.1 \mu \mathrm{g} \mathrm{C}$ $\mathrm{l}^{-1}$, Table 1). Irrespective of the inverse $20 \mu \mathrm{m}$ filtration, the biomass of the thecate dinoflagellates and that of other groups of the 10 to $20 \mu \mathrm{m}$ size range was enhanced by a factor of 1.7 to 2.6 , similar to the biomass of the larger groups. Therefore, only small differences in the relative taxonomic and size composition occurred between the treatments. Detritus could have clogged the sieve and reduced its effective mesh size allowing only small flagellates to pass through the filter. The similar composition in both treatments is also reflected in the similar $\mathrm{C} / \mathrm{N}$ weight ratio of 5.5 and 5.8 for the natural and the enriched treatments, respectively (Table 1).

The particulate organic carbon (POC) of 524 and $743 \mu \mathrm{g} \mathrm{l}^{-1}$ in the natural and in the enriched treatments was generally higher than estimates of total protist C by microscopy (Table 1). Detritus, pico- and nanoplankton not included in the microscopic analyses likely accounted for these differences. While the POC and the PON (particulate organic nitrogen) content increased by a factor of 1.4 from natural to enriched treatments, total fatty acid concentration increased from 39.4 to $89.3 \mu \mathrm{g} \mathrm{l}^{-1}$ or a factor of 2.3 (Table 2), similar to the increase in total protist carbon of 2.6. Apparently, protists were enriched in lipids compared to detritus or small pico- and nanoplankton. Differences in the relative composition of fatty acids between treatments were small (Table 2). The 16:0, 20:5(n-3) and 22:6(n-3) were the most important single fatty acids, followed by 14:0 and various 16- and 18-mono- and 
Table 2. Fatty acid composition (\% total fatty acids) and average total fatty acid concentration of the natural and enriched food suspensions used in feeding experiments (Day 1)

\begin{tabular}{|lcc|}
\hline Fatty acid & Natural & Enriched \\
\hline $14: 0$ & 6.5 & 7.9 \\
$15: 0$ & 2.1 & 2.2 \\
$16: 0$ & 21.7 & 20.7 \\
$17: 0$ & 0.4 & 0 \\
$18: 0$ & 5.3 & 4.6 \\
$14: 1(\mathrm{n}-5)$ & 1.5 & 1.4 \\
$16: 1(\mathrm{n}-5)$ & 2.3 & 2.1 \\
$16: 1(\mathrm{n}-7)$ & 4.1 & 4.1 \\
$16: 1(\mathrm{n}-9)$ & 2.3 & 2.3 \\
$18: 1(\mathrm{n}-7)$ & 5.0 & 3.9 \\
$18: 1(\mathrm{n}-9)$ & 5.8 & 5.0 \\
$20: 1(\mathrm{n}-9) / 18: 5(\mathrm{n}-3)$ & 2.6 & 3.3 \\
$18: 2(\mathrm{n}-6)$ & 2.3 & 2.3 \\
$18: 3(\mathrm{n}-3)$ & 1.0 & 1.2 \\
$18: 4(\mathrm{n}-3)$ & 3.5 & 4.9 \\
$20: 5(\mathrm{n}-3)$ & 17.0 & 18.1 \\
$22: 5(n-3)$ & 1.0 & 0.8 \\
$22: 6(\mathrm{n}-3)$ & 15.6 & 15.1 \\
Saturated & 36 & 36 \\
Monounsaturated & 24 & 22 \\
Polyunsaturated & 40 & 42 \\
Total concentration $\left(\mu \mathrm{Hg} \mathrm{l}^{-1}\right)$ & 39.4 & 89.3 \\
EPA/DHA ratio & 0.9 & 0.8 \\
$(\mathrm{n}-3) /(\mathrm{n}-6)$ ratio & 16.8 & 17.3 \\
\hline
\end{tabular}

polyunsaturated fatty acids. The ratio of (n-3) to (n-6) fatty acids and of eicosapentaenoic acid (EPA, 20:5(n3)) to docosahexaenoic acid (DHA, 22:6(n-3)), which are an important characteristic of food quality, were similar in both treatments and ranged from 0.8 to 0.9 and 16.8 to 17.3 , respectively.

\section{Variation of food concentration during incubation}

The composition of the seston fed to copepods in both experimental treatments varied only little in the course of the experiment (Fig. 2). Flagellates dominated the composition of the seston numerically throughout the experiment, with a similar abundance in the natural and enriched treatments $(295 \pm 24$ and $331 \pm 29 \times 10^{3}$ cells $1^{-1}$, respectively). Ciliates and dinoflagellates dominated the seston biomass with little change over time and also remained consistently enhanced in the enriched treatment throughout the experiments. Biomass averaged $52 \pm 3.1$ and $119 \pm$ $21.1 \mu \mathrm{g} \mathrm{C} \mathrm{l}^{-1}$ for dinoflagellates, and $92 \pm 12.3$ and $240 \pm 33.2 \mu \mathrm{g} \mathrm{C} \mathrm{l^{-1 }}$ for ciliates in the natural and enriched treatments, respectively. However, in contrast to the relatively stable composition of major groups, a small shift in the composition of large ciliates was observed. While the biomass of Laboea strobila
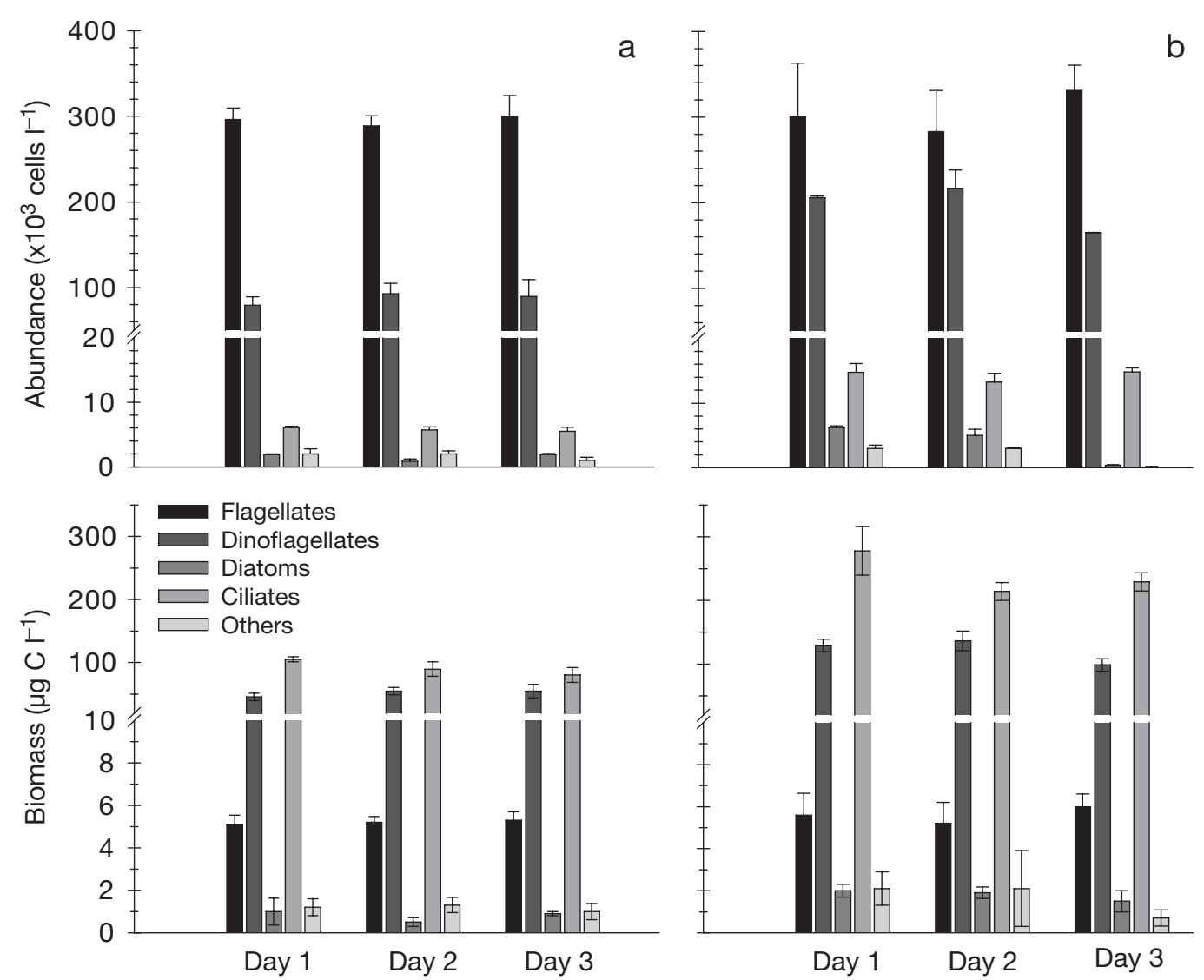

Fig. 2. Temporal variation of protist abundance (cells $\mathrm{l}^{-1} \pm \mathrm{SD}$ ) and biomass ( $\mu \mathrm{g} \mathrm{C} \mathrm{^{-1 }}$ $\pm \mathrm{SD}$ ) of main taxonomic groups in (a) natural and (b) enriched food suspensions over the course of the experiment 
was constant (natural treatment: $48 \pm 2.5$ to $55 \pm 1.9 \mu \mathrm{g}$ $\mathrm{C}^{-1}$ ) or increased (enriched treatment: $122 \pm 10.5$ to $163 \pm 10.1 \mu \mathrm{g} \mathrm{C}^{-1}$ ), the biomass of the Strobiliidae declined over the days of incubation (natural treatment: $55 \pm 5.1$ to $24 \pm 6.8 \mu \mathrm{g} \mathrm{C} \mathrm{l}^{-1}$; enriched treatment: $153 \pm 27.9$ to $62 \pm 3.4 \mu \mathrm{g} \mathrm{C} \mathrm{l}^{-1}$ ). Variations within the other groups were small.

\section{$\mathrm{C}, \mathrm{N}$ and fatty acids in size fractions}

In order to break down the bulk measurements for the nutritional value of seston into its different components, the taxonomic composition, fatty acid and mineral content were determined in different size fractions $(<20,<48$ and $<100 \mu \mathrm{m})$ on Day 3 of the study (Tables 3 $\& 4)$. The composition of the 20 to $48 \mu \mathrm{m}$ and the 48 to $100 \mu \mathrm{m}$ size fractions were obtained by subtraction of the respective smaller fraction from the larger one. As shown below, these 2 size fractions reflect the diets of Acartia clausi better than the bulk measurements in both treatments.
The fractionation of seawater in the natural treatment resulted in a total protist biomass of $50.8 \pm$ $3.38 \mu \mathrm{g} \mathrm{C}^{-1}$ in the $<20 \mu \mathrm{m}$ fraction and $142.3 \pm$ $13.46 \mu \mathrm{g} \mathrm{C}^{-1}$ in the $<48 \mu \mathrm{m}$ fraction (Table 3 ). Due to the removal of large particles by the $20 \mu \mathrm{m}$ sieve, the size fractions differed mainly in the biomass of larger protists, while the biomass of flagellates was similar. As a consequence, the biomass of $91.4 \mu \mathrm{g} \mathrm{C} \mathrm{l}^{-1}$ calculated for the 20 to $48 \mu \mathrm{m}$ fraction by subtraction consisted mainly of Laboea strobila (59.6 $\mu \mathrm{g} \mathrm{C}^{-1}, 63.7 \%$ of the biomass) and Strobiliidae (12.5 $\left.\mu \mathrm{C} \mathrm{C} \mathrm{l}^{-1}, 13.4 \%\right)$, but also thecate dinoflagellates $<20 \mu \mathrm{m}\left(12.4 \mu \mathrm{g} \mathrm{C}{ }^{-1}\right.$, $13.2 \%)$ and athecate dinoflagellates $>30 \mu \mathrm{m}(4.5 \mu \mathrm{g} \mathrm{C}$ $\mathrm{l}^{-1}, 4.8 \%$ ). This composition largely resembled the diet of females in the natural treatment (see next section). The POC and PON content of the 20 to $48 \mu \mathrm{m}$ fraction amounted to $72 \mu \mathrm{g} \mathrm{Cl}^{-1}$ and $16 \mu \mathrm{g} \mathrm{N}^{-1}$ (Table 3). The $\mathrm{C} / \mathrm{N}$ weight ratio of 4.4 indicates that this fraction was enriched in nitrogen compared to the seston averages of 6.7 and 6.1 for the $<20$ and $<48 \mu \mathrm{m}$ fractions. Relating the POC and PON concentration to the average total protist volume of $479.5 \times 10^{6} \mu^{3}$ (data not shown)

Table 3. Taxonomic and size composition, particulate organic carbon (POC) and nitrogen (PON), and C/N ratio of size fractionated food suspensions from the natural and enriched treatments and of the calculated differences between size fractions (20 to $48 \mu \mathrm{m}, 48$ to $100 \mu \mathrm{m}$ ) on Day 3 of the study

\begin{tabular}{|c|c|c|c|c|c|c|c|c|}
\hline & \multicolumn{4}{|c|}{-Natural treatment -} & \multicolumn{4}{|c|}{ Enriched treatment } \\
\hline & $\begin{array}{c}<20 \mu \mathrm{m} \\
\left(\mu \mathrm{g} \mathrm{Cl}^{-1}\right)\end{array}$ & $\begin{array}{c}<48 \mu \mathrm{m} \\
\left(\mu \mathrm{C}^{-1}\right)\end{array}$ & $\begin{array}{r}20-48 \\
\left(\mu \mathrm{C}^{-1}\right)\end{array}$ & m & $\begin{array}{l}<48 \mu \mathrm{m} \\
\left(\mu \mathrm{C} \mathrm{Cl}^{-1}\right)\end{array}$ & $\begin{array}{l}<100 \mu \mathrm{m} \\
\left(\mu \mathrm{C} \mathrm{C}^{-1}\right)\end{array}$ & $\begin{array}{r}48-100 \\
\left(\mu g \mathrm{Cl}^{-1}\right)\end{array}$ & $\mu_{\%}$ \\
\hline \multicolumn{9}{|l|}{ Flagellates } \\
\hline$<10 \mu \mathrm{m}$ & $5.1 \pm 0.03$ & $4.7 \pm 0.07$ & -0.4 & - & $5.0 \pm 0.35$ & $5.2 \pm 0.57$ & 0.2 & 0.2 \\
\hline$<20 \mu \mathrm{m}$ & $0.8 \pm 0.06$ & $1.1 \pm 0.09$ & 0.3 & 0.3 & $0.7 \pm 0.04$ & $0.7 \pm 0.02$ & 0.0 & - \\
\hline$<30 \mu \mathrm{m}$ & $0.1 \pm 0.06$ & $0.1 \pm 0.07$ & 0.0 & - & $0.1 \pm 0.01$ & $0.2 \pm 0.03$ & 0.1 & 0.1 \\
\hline \multicolumn{9}{|l|}{ Dinoflagellates } \\
\hline Athecate $<20 \mu \mathrm{m}$ & $1.6 \pm 0.37$ & $3.1 \pm 0.32$ & 1.5 & 1.6 & $3.1 \pm 0.09$ & $3.5 \pm 0.16$ & 0.4 & 0.3 \\
\hline Thecate $<20 \mu \mathrm{m}$ & $24.2 \pm 3.42$ & $36.6 \pm 4.52$ & 12.4 & 13.2 & $66.0 \pm 7.44$ & $68.1 \pm 8.77$ & 2.1 & 1.8 \\
\hline Athecate $<30 \mu \mathrm{m}$ & $1.0 \pm 0.09$ & $0.8 \pm 0.07$ & -0.2 & - & $1.8 \pm 0.09$ & $1.3 \pm 0.04$ & -0.6 & - \\
\hline Thecate $<30 \mu \mathrm{m}$ & $1.7 \pm 0.15$ & $3.3 \pm 0.82$ & 1.5 & 1.6 & $4.0 \pm 1.01$ & $2.4 \pm 0.55$ & -1.6 & - \\
\hline Athecate $>30 \mu \mathrm{m}$ & $5.7 \pm 0.53$ & $10.2 \pm 1.81$ & 4.5 & 4.8 & $14.9 \pm 2.09$ & $15.6 \pm 1.87$ & 0.8 & 0.7 \\
\hline Thecate $>30 \mu \mathrm{m}$ & $0.8 \pm 0.44$ & $1.7 \pm 0.07$ & 0.8 & 0.9 & $6.6 \pm 0.15$ & $4.9 \pm 0.17$ & -1.7 & - \\
\hline \multicolumn{9}{|l|}{ Diatoms } \\
\hline$<20 \mu \mathrm{m}$ & $0.0 \pm 0.02$ & $0.1 \pm 0.08$ & 0.1 & 0.1 & $0.1 \pm 0.05$ & $0.0 \pm 0.07$ & -0.1 & - \\
\hline$>30 \mu \mathrm{m}$ & - & $0.0 \pm 0.03$ & 0.0 & - & $0.8 \pm 0.22$ & $1.5 \pm 0.54$ & 0.7 & 0.6 \\
\hline \multicolumn{9}{|l|}{ Ciliates } \\
\hline$<20 \mu \mathrm{m}$ & $0.2 \pm 0.07$ & $0.2 \pm 0.05$ & 0.0 & - & $0.6 \pm 0.08$ & $0.2 \pm 0.03$ & -0.4 & - \\
\hline$<30 \mu \mathrm{m}$ & $0.9 \pm 0.12$ & $0.5 \pm 0.09$ & -0.4 & - & $1.2 \pm 0.02$ & $1.0 \pm 0.13$ & -0.2 & - \\
\hline Laboea strobila $>30 \mu \mathrm{m}$ & - & $59.6 \pm 6.37$ & 59.6 & 63.7 & $71.0 \pm 4.23$ & $163.2 \pm 5.56$ & 92.2 & 77.2 \\
\hline Strobiliidae $>30 \mu \mathrm{m}$ & $4.8 \pm 1.96$ & $17.3 \pm 1.96$ & 12.5 & 13.4 & $39.1 \pm 5.49$ & $62.0 \pm 0.49$ & 22.8 & 19.1 \\
\hline Others $>30 \mu \mathrm{m}$ & $1.5 \pm 0.29$ & $1.9 \pm 0.26$ & 0.4 & 0.4 & $2.6 \pm 0.37$ & $2.8 \pm 0.22$ & 0.2 & 0.2 \\
\hline Others & $2.2 \pm 0.54$ & $1.1 \pm 0.45$ & -1.1 & - & $0.7 \pm 0.38$ & $0.6 \pm 0.38$ & -0.1 & - \\
\hline Total & $50.8 \pm 3.38$ & $142.3 \pm 13.46$ & 91.4 & 100 & $218.2 \pm 9.98$ & $331.1 \pm 22.95$ & 114.9 & 100 \\
\hline $\mathrm{POC}\left(\mu \mathrm{g} \mathrm{C} \mathrm{l}^{-1}\right)$ & 261.2 & 333.4 & 72 & & 499.0 & 645.2 & 146.2 & \\
\hline $\mathrm{PON}\left(\mu \mathrm{g} \mathrm{N} \mathrm{l^{-1 }}\right)$ & 38.3 & 55.0 & 16 & & 80.4 & 110.2 & 29.8 & \\
\hline $\mathrm{C} / \mathrm{N}$ & 6.7 & 6.1 & 4.4 & & 6.2 & 5.9 & 4.9 & \\
\hline Specific C $\left(p g \mu \mathrm{m}^{-3}\right)$ & 0.88 & 0.43 & 0.15 & & 0.42 & 0.36 & 0.24 & \\
\hline Specific $N\left(\mathrm{pg} \mu \mathrm{m}^{-3}\right)$ & 0.13 & 0.07 & 0.03 & & 0.07 & 0.06 & 0.05 & \\
\hline
\end{tabular}


Table 4. Composition of fatty acids (\% total fatty acids), average fatty acid concentration $\left(\mu \mathrm{g} \mathrm{l}^{-1}\right)$, volume-specific fatty acid contents $\left(\mathrm{fg} \mu \mathrm{m}^{-3}\right)$, and EPA/DHA and $(n-3) /(n-6)$ ratios in fractionated food suspensions from the natural and enriched treatments on Day 3 of the study

\begin{tabular}{|c|c|c|c|c|c|c|}
\hline Fatty acid & $<20 \mu \mathrm{m}$ & $\begin{array}{l}- \text { Natural } \\
<48 \mu \mathrm{m}\end{array}$ & $\overline{20-48 \mu \mathrm{m}}$ & $<48 \mu \mathrm{m}$ & $\begin{array}{l}\text { Enriched- } \\
<100 \mu \mathrm{m}\end{array}$ & $\overline{48-100 \mu \mathrm{m}}$ \\
\hline $14: 0$ & 4.7 & 5.0 & 5.2 & 5.0 & 7.3 & 12.2 \\
\hline $15: 0$ & 1.9 & 1.7 & 1.5 & 1.9 & 2.2 & 2.6 \\
\hline $16: 0$ & 22.4 & 20.2 & 18.2 & 19.5 & 21.7 & 22.5 \\
\hline $17: 0$ & 0.8 & 0.8 & 0.8 & 0 & 0.9 & 0.3 \\
\hline $18: 0$ & 5.3 & 4.4 & 3.6 & 3.7 & 5.1 & 6.0 \\
\hline $14: 1(n-5)$ & 1.5 & 1.3 & 1.1 & 1.4 & 1.0 & 1.5 \\
\hline $16: 1(n-5)$ & 3.3 & 2.5 & 1.6 & 2.4 & 2.8 & 1.7 \\
\hline $16: 1(n-7)$ & 4.8 & 4.0 & 3.3 & 4.5 & 4.9 & 3.5 \\
\hline $16: 1(n-9)$ & 3.5 & 2.5 & 1.7 & 2.2 & 3.0 & 2.4 \\
\hline $18: 1(n-7)$ & 6.8 & 4.4 & 2.2 & 3.8 & 3.3 & 4.1 \\
\hline $18: 1(n-9)$ & 6.2 & 5.6 & 5.1 & 5.7 & 6.7 & 4.0 \\
\hline $20: 1(n-9) / 18: 5(n-3)$ & 3.4 & 3.6 & 3.7 & 4.9 & 2.6 & 1.0 \\
\hline $18: 2(n-6)$ & 2.6 & 2.5 & 2.5 & 2.4 & 2.3 & 2.2 \\
\hline $18: 3(n-3)$ & 1.5 & 1.7 & 2.0 & 1.9 & 1.1 & 0.2 \\
\hline $18: 4(n-3)$ & 3.8 & 5.0 & 6.0 & 7.0 & 3.1 & 1.8 \\
\hline $20: 5(n-3)$ & 10.3 & 14.7 & 18.7 & 15.2 & 18.5 & 22.2 \\
\hline $22: 5(n-3)$ & 0.5 & 0.5 & 0.5 & 0.8 & 1.0 & 0.9 \\
\hline $22: 6(n-3)$ & 16.3 & 19.7 & 22.7 & 17.8 & 15.1 & 11.4 \\
\hline Saturated & 35 & 32 & 29 & 30 & 37 & 43 \\
\hline Monounsaturated & 30 & 24 & 19 & 23 & 22 & 20 \\
\hline Polyunsaturated & 35 & 44 & 52 & 45 & 41 & 39 \\
\hline Total conc. $\left(\mu \mathrm{g} \mathrm{l}^{-1}\right)$ & 14.4 & 30.2 & 15.8 & 50.6 & 71.5 & 20.9 \\
\hline $\begin{array}{l}\text { Volume-specific } \\
\text { contents }\left(\mathrm{fg} \mu \mathrm{m}^{3}\right)\end{array}$ & 48 & 39 & 33 & 43 & 40 & 35 \\
\hline EPA/DHA ratio & 0.6 & 0.7 & 0.8 & 0.9 & 1.2 & 1.9 \\
\hline$(n-3) /(n-6)$ ratio & 10.8 & 16.4 & 23.3 & 17.9 & 17.3 & 16.3 \\
\hline
\end{tabular}

flagellates, diatoms and small ciliates, but differed strongly in the biomass of large ciliates. Hence, the difference of $114.9 \mu \mathrm{g} \mathrm{C}^{-1}$ between them (the 48 to $100 \mu \mathrm{m}$ fraction) consisted of Laboea strobila (92.2 $\mu \mathrm{g} \mathrm{C} \mathrm{l}^{-1}, 77.2 \%$ of the biomass in this fraction), Strobiliidae $\left(22.8 \mu \mathrm{g} \mathrm{C} \mathrm{l}^{-1}, 19.1 \%\right)$ and very few dinoflagellates (combined $3.3 \mu \mathrm{g} \mathrm{C}^{-1}$, $2.5 \%$ ). Again, this composition resembled the diet of females in the enriched treatment (see next section). The differences in the mineral and biochemical content of the size fractions can, therefore, largely be attributed to ciliates. The average POC and PON contents were 499.0 and $645.2 \mu \mathrm{g} \mathrm{C} \mathrm{Cl}^{-1}$, and 80.4 and $110.2 \mu \mathrm{g} \mathrm{N}^{-1}$ for the $<48$ and $<100 \mu \mathrm{m}$ fractions, respectively. This yielded 146.2 $\mu \mathrm{g} \mathrm{Cl}^{-1}, 29.8 \mu \mathrm{g} \mathrm{N}{ }^{-1}$ and a $\mathrm{C} / \mathrm{N}$ weight ratio of 4.9 for the 48 to $100 \mu \mathrm{m}$ fraction. Based on a protist volume of $603.5 \times 10^{6}{\mu \mathrm{m}^{3}}$ for this fraction, the volume-specific $\mathrm{C}$ and $\mathrm{N}$ contents were 0.24 and $0.05 \mathrm{pg} \mu \mathrm{m}^{-3}$, respectively. The difference in the fatty acid content between the $<48$ and $<100 \mu \mathrm{m}$ fraction was $20.9 \mathrm{\mu g}^{-1}$ and the calculated volume-specific fatty acid content for the 48 to $100 \mu \mathrm{m}$ fraction

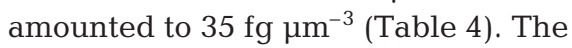
composition of the fatty acids in this

for the 20 to $48 \mu \mathrm{m}$ fraction yielded a volume-specific C and $\mathrm{N}$ content of 0.15 and $0.03 \mathrm{pg} \mathrm{m}^{-3}$, respectively (Table 3). The fatty acid concentration for the $<20$ and $<48 \mu \mathrm{m}$ fraction were 14.4 and $30.2 \mu \mathrm{g} \mathrm{l}^{-1}$, respectively, and thus amount to $15.8 \mu \mathrm{g} \mathrm{l}^{-1}$ for the 20 to $48 \mu \mathrm{m}$ fraction (Table 4). The volume-specific fatty acid content of the 20 to $48 \mu \mathrm{m}$ fraction of $33 \mathrm{fg}^{-3} \mathrm{~m}^{-3}$ was lower than the averages of 48 and $39 \mathrm{fg}^{-3} \mathrm{~m}^{-3}$ for the $<20$ and $<48 \mu \mathrm{m}$ fractions, respectively. However, this fraction was particularly rich in polyunsaturated fatty acids (PUFA, $52 \%$ of the total fatty acids) compared to the $<20 \mu \mathrm{m}(35 \%)$ and $<48 \mu \mathrm{m}(44 \%)$ fractions. The 22:6(n-3) and the 20:5(n-3) PUFAs were particularly enriched in the 20 to $48 \mu \mathrm{m}$ fraction, while the contribution of $16: 0$ and 18:1 declined compared to the $<20$ and $<48 \mu \mathrm{m}$ fractions. The (n-3)/(n-6) and the 20:5/22:6 ratios were 23.3 and 0.8 , respectively, and considerably higher than in the $<20$ and $<48 \mu \mathrm{m}$ fractions.

In the enriched treatment, the biomass of the $<48$ and $<100 \mu \mathrm{m}$ fractions was $218.2 \pm 9.98$ and $331.1 \pm$ $22.95 \mu \mathrm{g} \mathrm{C} \mathrm{l}^{-1}$, respectively (Table 3 ). Both size fractions showed a similar biomass for flagellates, dino- fraction differed strongly from the bulk composition of all other size fractions. PUFAs contributed only $39 \%$ to the total fatty acids while the contribution of saturated fatty acids was enhanced to $43 \%$. Among PUFAs, 20:5(n-3) was enriched (22\%), but the contribution of the 18:3(n-3), 18:4(n-3) and 22:6(n-3), in contrast, was lower than in the $<48$ and $<100 \mu \mathrm{m}$ fractions. The $(n-3) /(n-6)$ and the 20:5/22:6 ratios were 16.3 and 1.9 , respectively.

\section{Grazing and egg production of Acartia clausi}

The composition of the seston in controls showed only small changes during the incubation (Fig. 3). In the natural treatment, the biomass of flagellates and ciliates decreased from an average of $5.1 \pm 0.5$ to $3.7 \pm$

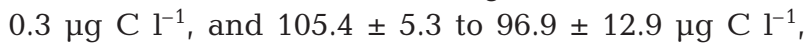
respectively, while no change was observed in the other groups. In the enriched treatment, the biomass of ciliates decreased from an average of $276.5 \pm 23.9$ to $236.2 \pm 12.6 \mu \mathrm{g} \mathrm{C} \mathrm{l}^{-1}$. Again, no major change was 

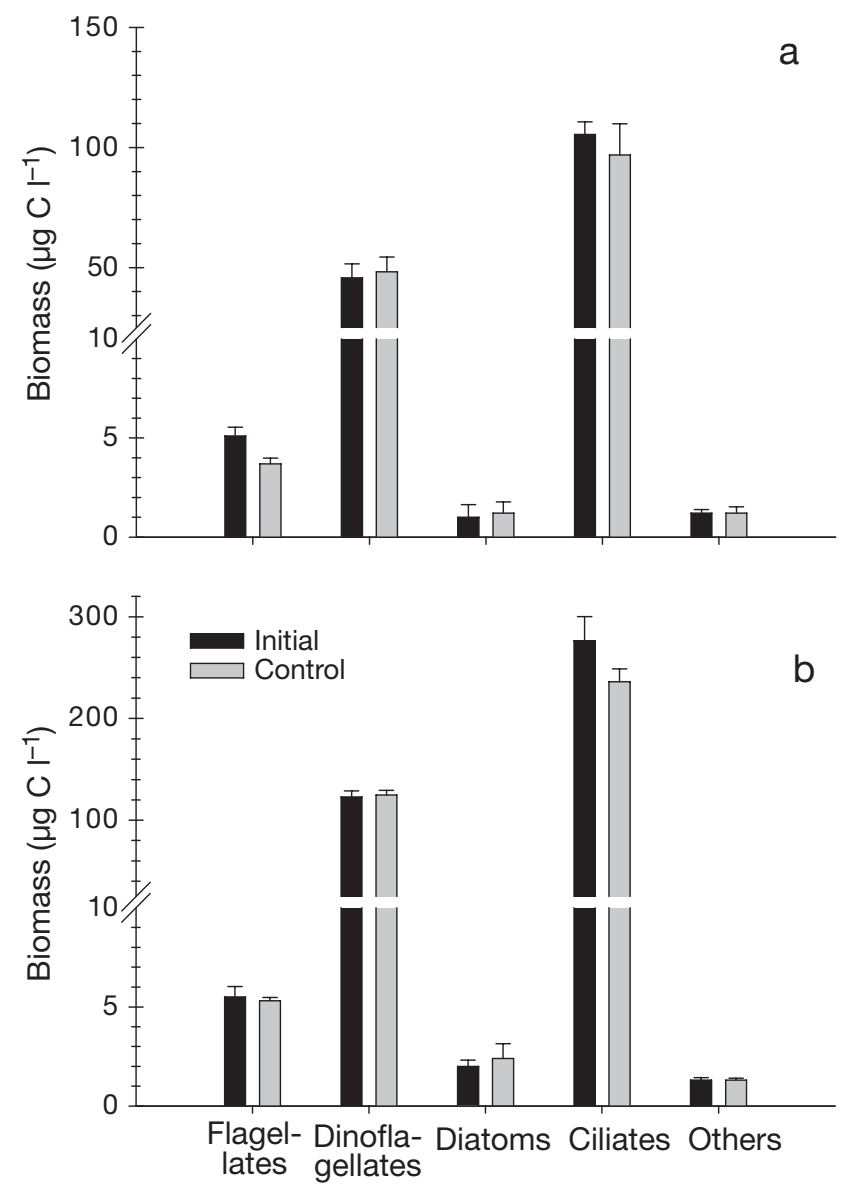

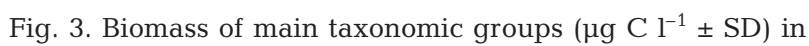
the initials and controls of (a) natural and (b) enriched food suspensions in the grazing experiments they were dominating; e.g. Rates on flagellates, dinoflagellates, diatoms and ciliates resembled those of the 5 to 10,10 to 20,20 to 30 and $>30 \mu \mathrm{m}$ size classes, respectively (Fig. 4). Thus, comparably high, but quite variable clearance rates $\left(0.5\right.$ to $1.9 \mathrm{ml}$ female $\left.\mathrm{f}^{-1} \mathrm{~h}^{-1}\right)$ were recorded on diatoms and ciliates while those on dinoflagellates and other protists tended to be lower $(0$ to $0.4 \mathrm{ml}$ female $^{-1} \mathrm{~h}^{-1}$ ), which was significant for diatoms in the natural treatment and for ciliates in both the natural and the enriched treatments (KruskalWallis test, $\mathrm{p}<0.001)$. However, clearance rates on single prey items were very heterogeneous with regard to their size, taxonomic group or biomass (Fig. 5). For instance, athecate dinoflagellates $>30 \mu \mathrm{m}$ were cleared at a lower rate than the smaller thecate dinoflagellates $<30 \mu \mathrm{m}$ although available at a similar biomass. On the other hand, they were cleared at a similar rate than thecate dinoflagellates $<20 \mu \mathrm{m}$ or Strobiliidae $>30 \mu \mathrm{m}$ although available at a much lower biomass. Also, clearance rates on Laboea strobila were considerably higher than on thecate dinoflagellates $<20 \mu \mathrm{m}$ or Strobiliidae $>30 \mu \mathrm{m}$ which had a similar or higher biomass.

Females ingested an average of $2.87 \pm 0.36 \mu \mathrm{g} \mathrm{C}$ female $\mathrm{e}^{-1} \mathrm{~d}^{-1}$ in the natural treatment, equivalent to a daily ration of $55 \%$. Ciliates were the most important single dietary group (Fig. 6). Laboea strobila (prey category $14,1.65 \pm 0.54 \mu \mathrm{g}$ female $\mathrm{f}^{-1} \mathrm{~d}^{-1}$ ) and diverse Strobiliidae (prey category 15, $0.82 \pm 0.23 \mu \mathrm{g}$ C female $\mathrm{f}^{-1} \mathrm{~d}^{-1}$ ) together contributed more than $86 \%$ to the diet (Figs. $6 \&$ 7). Apart from the large ciliates, small thecate dinoflagellates (10 to $20 \mu \mathrm{m})$ also con- observed in the other groups. Thus, realistic clearance rates were obtained in both treatments.

Total clearance rates of females were $0.77 \pm 0.17$ and $0.55 \pm 0.10 \mathrm{ml}$ female $\mathrm{e}^{-1} \mathrm{~h}^{-1}$ for the natural and the enriched treatments, respectively (Fig. 4). Clearance was related to prey size in both treatments, but no clear relationship to prey biomass was observed. While negative clearance was recorded on cells of 5 to $10 \mu \mathrm{m}$, average clearance rates on cells of 10 to $20 \mu \mathrm{m}$ size $(0.3$ and $0.1 \mathrm{ml}$ female $^{-1} \mathrm{~h}^{-1}$ for the natural and the enriched treatments) were significantly lower than those on cells of 20 to $30 \mu \mathrm{m}$ (1.5 and $0.4 \mathrm{ml}$ female $^{-1} \mathrm{~h}^{-1}$ ) and $>30 \mu \mathrm{m}\left(0.6\right.$ and $0.7 \mathrm{ml}$ female $\left.{ }^{-1} \mathrm{~h}^{-1}\right)$ within each treatment (Kruskal-Wallis test, p $<0.001$ ). Furthermore, clearance rates on major size and prey groups tended to be lower in the enriched treatment than in the natural treatment, particularly for diatoms and protists of 20 to $30 \mu \mathrm{m}$ size (Fig. 4). Clearance rates on the major prey groups closely followed those of the size classes in which

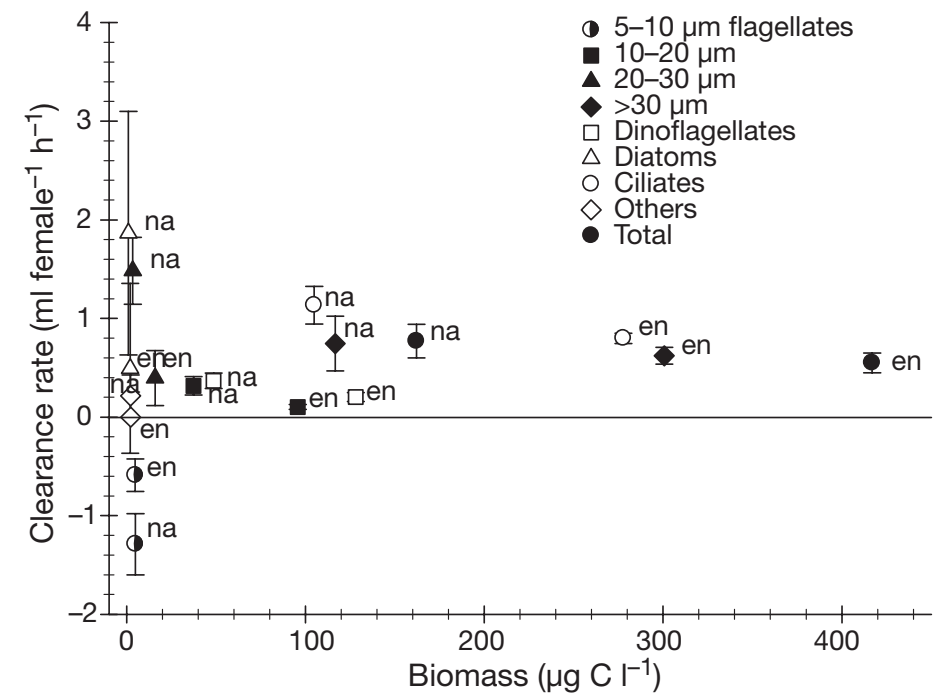

Fig. 4. Acartia clausi. Clearance rates $\left(\mathrm{ml}\right.$ female $\left.\mathrm{e}^{-1} \mathrm{~h}^{-1} \pm \mathrm{SD}\right)$ vs. prey biomass for different prey size classes (filled symbols) or prey categories (open symbols) in natural (na) or in enriched (en) food suspensions 

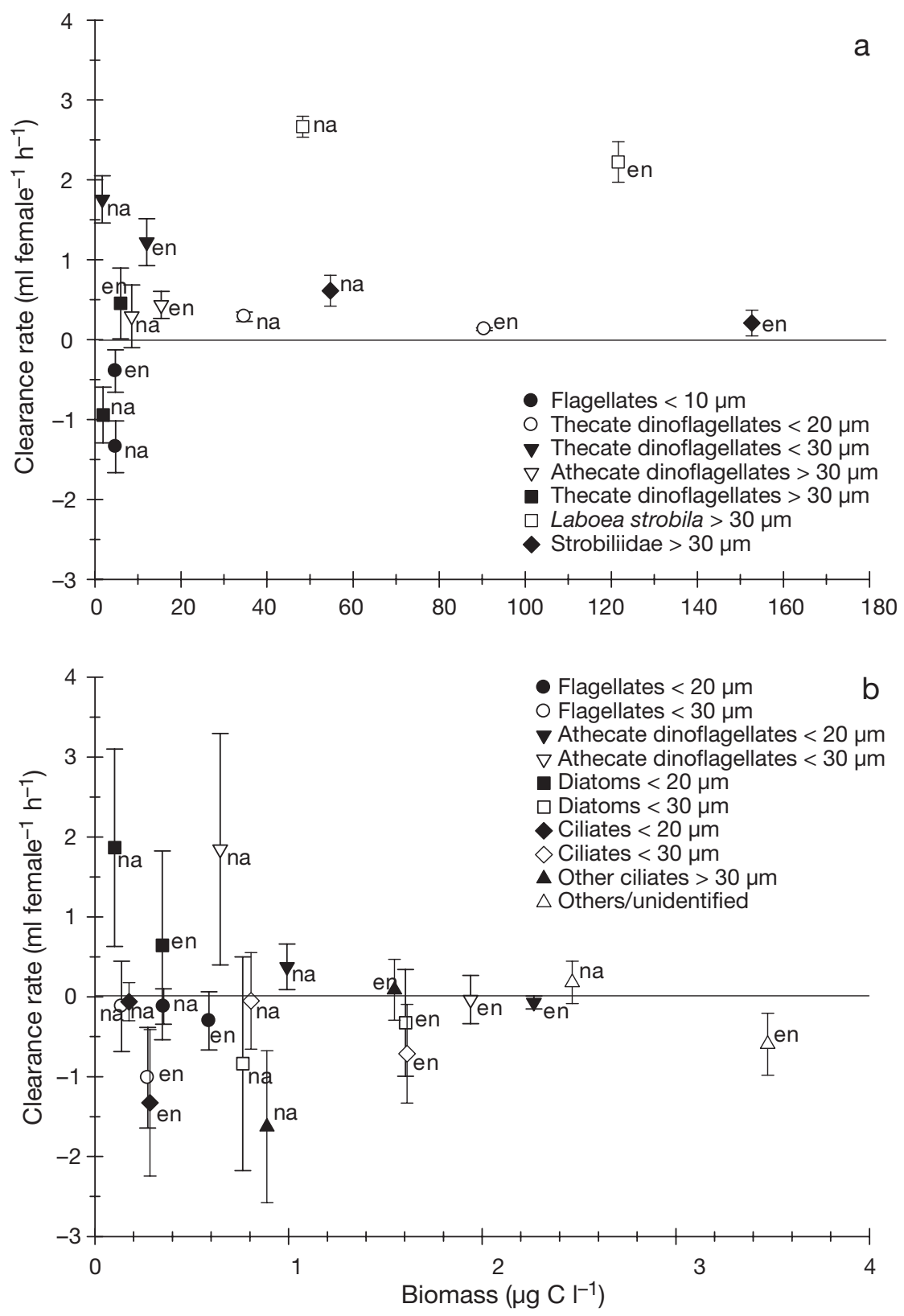

Fig. 5. Acartia clausi. Clearance rates $\left(\mathrm{ml}\right.$ female $\left.\mathrm{e}^{-1} \mathrm{~h}^{-1} \pm \mathrm{SD}\right)$ vs. biomass of protist prey in the natural (na) and in the enriched (en) treatments with a biomass (a) $>4 \mu \mathrm{g} \mathrm{Cl}^{-1}$ and (b) $<4 \mu \mathrm{g} \mathrm{C} \mathrm{l^{-1 }}$

tributed substantially to the diet (prey category 5, $0.23 \pm 0.05 \mu \mathrm{g} \mathrm{C}$ female $\mathrm{e}^{-1} \mathrm{~d}^{-1}$ ), while other dinoflagellates and other groups combined were of minor importance $\left(0.16 \pm 0.06 \mu \mathrm{g}\right.$ female fem $\left.^{-1} \mathrm{~d}^{-1}\right)$. Laboea strobila and thecate dinoflagellates of 20 to $30 \mu \mathrm{m}$ size (prey category 7) were significantly positively selected food items (1-sample $t$-test, $\mathrm{p}<0.01$ and $\mathrm{p}<$ 0.05 , respectively), but not the small thecate dinoflagellates $<20 \mu \mathrm{m}$ nor the Strobiliidae (Fig. 8). In the enriched treatment, females ingested an average of
$4.81 \pm 0.71 \mu \mathrm{g} \mathrm{C}$ female ${ }^{-1} \mathrm{~d}^{-1}$, which is equivalent to a daily ration of $92 \%$. Similar to the natural treatment, large ciliates dominated the diet (Fig. 6). Laboea strobila and Strobiliidae were ingested at rates of $3.59 \pm 0.29$ and $0.74 \pm 0.21 \mu \mathrm{g} C$ female ${ }^{-1} \mathrm{~d}^{-1}$, respectively, and together accounted for more than $90 \%$ of the diet (Fig. 7). The ingestion of dinoflagellates combined amounted to $0.46 \pm 0.07 \mu \mathrm{g} \mathrm{C}$ female $\mathrm{d}^{-1}$, with various athecate and thecate dinoflagellates (prey categories 5, 7 to 9) contributing about equally to the ingestion rate $(0.05$ to $0.14 \mu \mathrm{g} C$ female ${ }^{-1} \mathrm{~d}^{-1}$ ). Laboea strobila was the only food item which was positively selected in the enriched treatment. (1-sample $t$-test, $\mathrm{p}<0.01$ ) (Fig. 8). Dinoflagellates $>20 \mu \mathrm{m}$, ciliates $>20 \mu \mathrm{m}$ and diatoms $<30 \mu \mathrm{m}$ were ingested in proportion to their availability, while all other groups were selected against (1-sample $t$-test, $\mathrm{p}<0.05$ and $\mathrm{p}<0.01)$.

Egg production of females collected from the field displayed little variation over the 3 consecutive days of sampling and ranged from an average of $25 \pm 3.9$ to $27 \pm 4.5$ eggs female ${ }^{-1} \mathrm{~d}^{-1}$ (Fig. 9). The hatching success of eggs was invariably high and ranged from $77 \pm 11.4$ to $85 \pm 2.8 \%$. Egg production and hatching success in the natural treatment were $25 \pm 1.1$ eggs female ${ }^{-1}$ $\mathrm{d}^{-1}$ and $86 \pm 2.9 \%$, respectively, and not significantly different from the in-situ rates (1-way ANOVA; $\mathrm{p}>0.05$ ). In contrast, egg production in the enriched treatment increased significantly to $43 \pm 3.6$ eggs female $\mathrm{f}^{-1}$ (1-way ANOVA $F_{2}=57.1, \mathrm{p}<0.001$, Tukey HSD $\mathrm{p}<0.05)$, while hatching rates remained high $(83 \pm 11.4 \%)$. The egg diameter was similar in both treatments $\left(t_{\mathrm{s}}=1.1, \mathrm{p}>0.5\right)$; The C-specific egg production was therefore calculated from the overall average diameter of $81 \pm 2.1 \mu \mathrm{m}$. The specific ingestion and egg production rates had averages of $0.55 \pm 0.07$ and $0.21 \pm 0.012 \mathrm{~d}^{-1}$, and $0.92 \pm 0.141$ and $0.32 \pm 0.029 \mathrm{~d}^{-1}$ for the natural and the enriched treatments, respectively (Table 5). The calculated efficiency of egg production (EPE) of 0.39 and 0.35 did not differ between the natural and the enriched treatments (Table 5). 


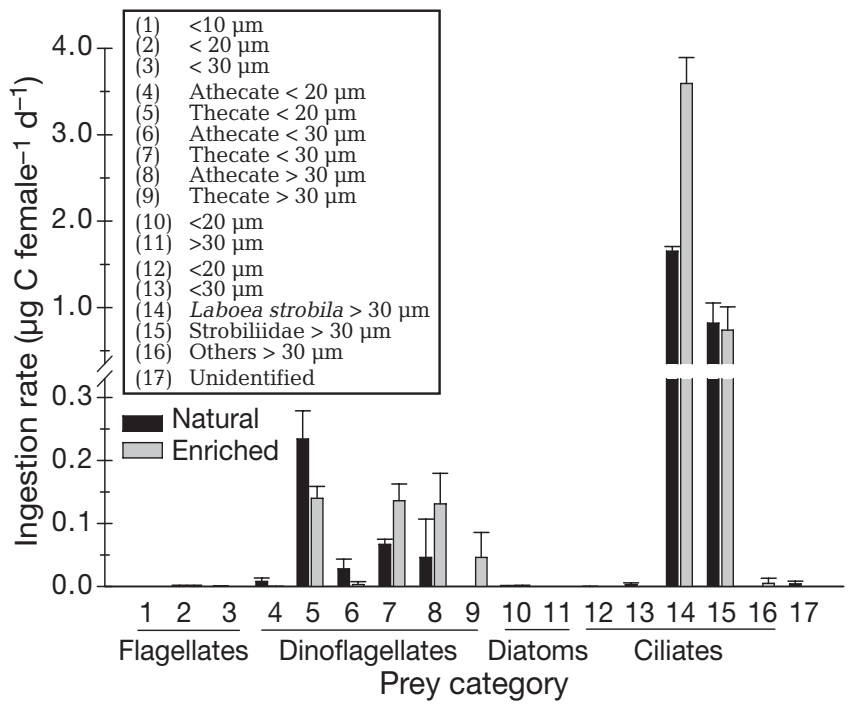

Fig. 6. Acartia clausi. Ingestion rates $\left(\mu \mathrm{g} \mathrm{C}\right.$ female $\left.{ }^{-1} \mathrm{~d}^{-1} \pm \mathrm{SD}\right)$ on different prey categories in the natural and enriched treatments

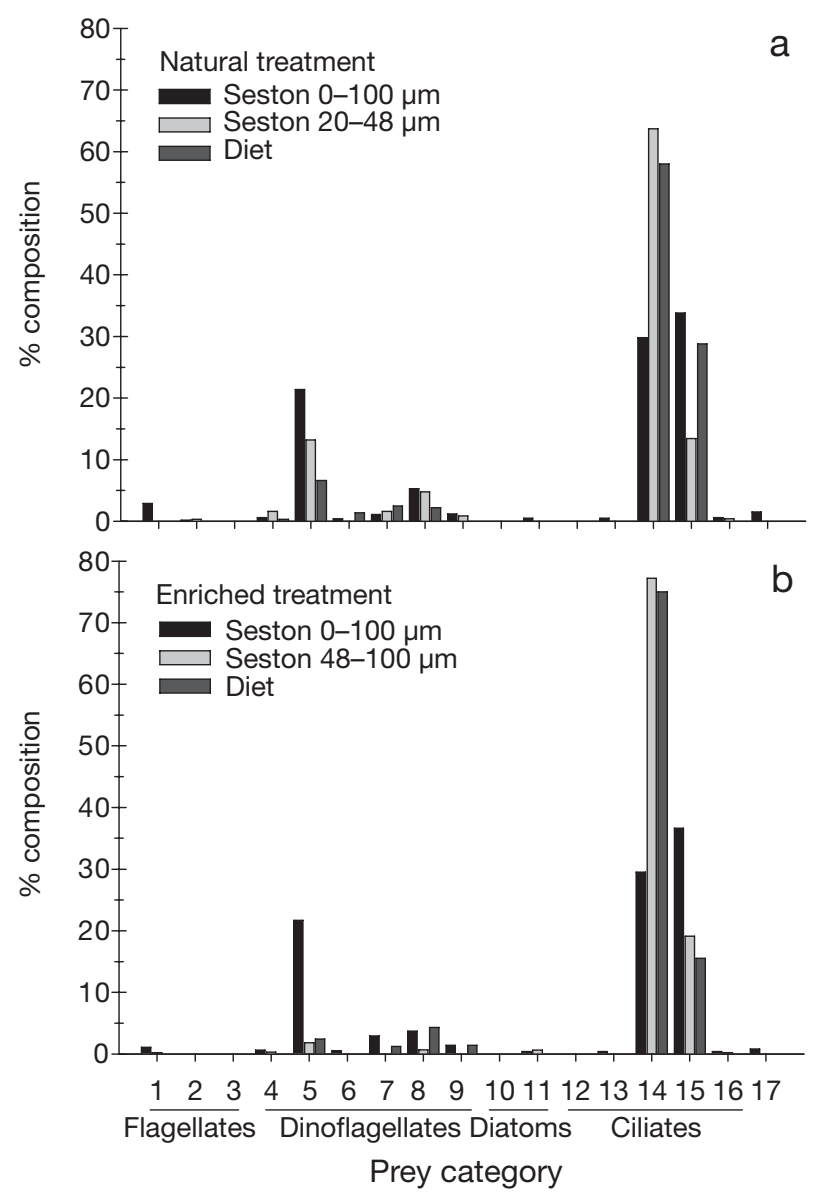

Fig. 7. Average composition (\%) of (a) bulk seston (0 to $100 \mu \mathrm{m}$ ), the size fraction 20 to $48 \mu \mathrm{m}$ and the diet of female Acartia clausi in the natural treatment, and (b) bulk seston ( 0 to $100 \mu \mathrm{m}$ ), the size fraction 48 to $100 \mu \mathrm{m}$ and the diet of females in the enriched treatment. Numbers indicate prey categories as denoted in Fig. 6

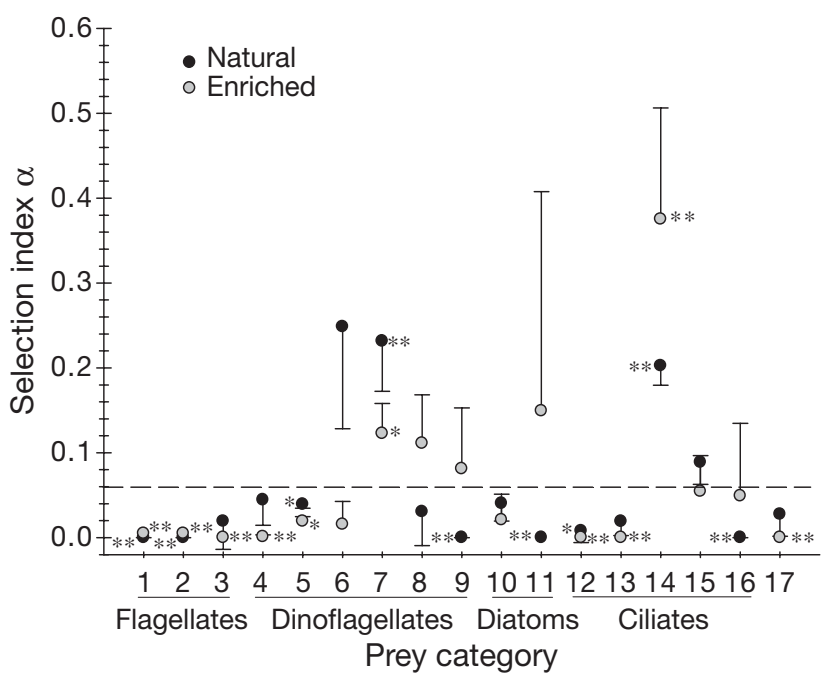

Fig. 8. Selectivity indices $\alpha$ calculated for prey in the natural and in the enriched treatments. Numbers indicate prey categories as denoted in Fig. 6 ; * significant selection for prey items ( $t$-test): $* \mathrm{p}<0.05, * * \mathrm{p}<0.01$. Dashed line indicates $\alpha=$ $1 /$ (number of prey categories) $=0.06$, at which feeding is non-selective. Error bars are SD

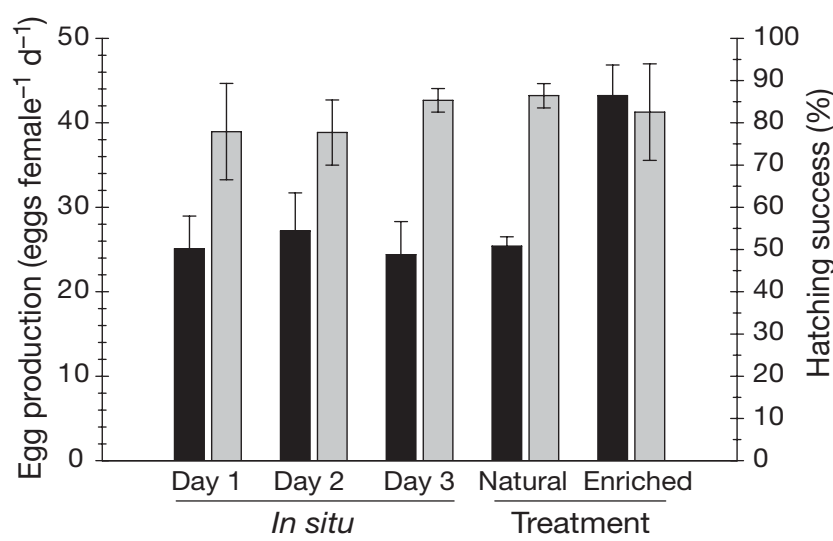

Fig. 9. Acartia clausi. Egg production (eggs female ${ }^{-1} \mathrm{~d}^{-1} \pm \mathrm{SD}_{\text {; }}$ black bars) and hatching success of eggs ( $\% \pm \mathrm{SD}_{\text {; grey bars) }}$ during the 3 consecutive days in the field and after $4 \mathrm{~d}$ of incubation in the natural and enriched treatments

\section{DISCUSSION}

During our investigation which was conducted after the spring phytoplankton bloom, large ciliates were the dominant component of the seston biomass and the preferred food source for Acartia clausi. This dominance together with an excellent nutritional quality of the diet composed of ciliates, particularly Laboea strobila and to a minor degree, of dinoflagellates, enabled a high reproductive success of females. This suggests that the spring recruitment of Acartia clausi might be partly related to the peak abundance of large heteroand mixotrophic ciliates occurring subsequent to the spring diatom bloom. 
Table 5. Acartia clausi. Mean $( \pm \mathrm{SD})$ carbon-specific ingestion $\left(\mathrm{IR}, \mu \mathrm{g} \mathrm{C} \mu \mathrm{g} \mathrm{C}^{-1}\right.$ $\mathrm{d}^{-1}$ ) and egg production rates (EPR, $\mu \mathrm{g} \mathrm{C} \mu \mathrm{g} \mathrm{C}^{-1} \mathrm{~d}^{-1}$ ) of females and the efficiency of egg production (EPE) calculated for the natural and enriched treatments and for the difference between both treatments (enriched minus natural)

\begin{tabular}{|lccc|}
\hline & Natural & Enriched & Difference \\
\hline IR & $0.55 \pm 0.070$ & $0.92 \pm 0.141$ & 0.37 \\
Flagellates & - & - & - \\
Dinoflagellates & $0.07 \pm 0.018$ & $0.09 \pm 0.014$ & 0.01 \\
Diatoms & $<0.001$ & $<0.001$ & $<0.001$ \\
Ciliates & $0.48 \pm 0.018$ & $0.83 \pm 0.128$ & 0.36 \\
Others & $<0.001$ & $<0.001$ & $<0.001$ \\
EPR & $0.21 \pm 0.012$ & $0.32 \pm 0.029$ & 0.11 \\
EPE (土 range) & $0.39 \pm(0.32-0.44)$ & $0.35 \pm(0.26-0.40)$ & 0.30 \\
\hline
\end{tabular}

\section{Methodology}

Ciliates are very fragile organisms sensitive to handling and fixation (Gifford 1985, Stoecker et al. 1994). The manipulation of water samples by size fractionation and inverse filtration in our study, therefore, bears the risk of severe underestimation of ciliate abundance and consumption by copepods. Strongly reduced cell concentrations with losses exceeding $70 \%$ of the initial number have been recorded for sieved oligotrich ciliates, whereas the abundance of tintinnids was found to be unaffected (Gifford 1985). Tiselius (1989), in contrast, did not observe a pronounced effect of sieving on seston composition, but reported some severe mortality of ciliates of over $80 \%$ during subsequent incubation. Since no initial samples from the collecting bottles without any additional handling were taken in our study, the reported abundance and biomass of ciliates should be regarded as conservative. However, the increase of total ciliate abundance by a factor of 2.6 (range for different ciliate size classes: 1.7 to 2.7 ) in the enriched treatment compared to the natural treatment compares well with the similar increase in the abundance of total dinoflagellates by a factor of 2.6 (range: 1.9 to 5.9), which are expected to be more robust. This suggests that the inverse filtration did not exert a strong detrimental effect on the abundance of ciliates, which might be related to the dominance of large species in the seston.

Although Lugol's acidic solution has been considered as one of the least detrimental preservatives for estimates of ciliate abundance (Leakey et al. 1994, Stoecker et al. 1994), losses due to fixation can range from 0 to $30 \%$ (Vincent \& Hartman 2001, Broglio et al. 2003, 2004) and cause an additional underestimate of ciliate consumption by copepods. Since losses are species-specific, and no estimates of the effect of Lugol's solution on the cell integrity of large Laboea strobila and various Strobiliidae yet exist, we did not correct ciliate counts for potential fixation artifacts. Applying a maximal loss factor of $30 \%$, average total ingestion rates would rise from 2.9 to $3.6 \mu \mathrm{g} \mathrm{C}$ female $\mathrm{f}^{-1} \mathrm{~d}^{-1}$ and from 4.8 to $6.1 \mu \mathrm{g} \mathrm{C}$ female $^{-1} \mathrm{~d}^{-1}$ for the natural and the enriched treatments, respectively. As a consequence, the efficiency of egg production (EPE) would decrease from 0.39 to 0.31 and from 0.35 to 0.27 . However, the correction would only slightly change the overall dominance of large ciliates in the seston and their high contribution to the diet of Acartia clausi with a strong preference for Laboea strobila. The absolute values for volume-specific mineral and biochemical contents of the size fractions should be regarded as potentially overestimated, but again the conclusions on the biochemical composition of the size fractions is not affected by the lack of a correction for ciliate biomass.

As outlined by Nejstgaard et al. (1997, 2001), under certain conditions, food rations of copepods can also be severely underestimated in grazing experiments that involve more than 2 trophic levels. Due to carnivorous feeding by copepods and the subsequent relaxation of ciliate grazing pressure, any direct ingestion of small cells by copepods is masked by enhanced growth in experimental bottles relative to controls, and needs to be corrected. Nejstgaard et al. (2001) suggested adjusting the grazing coefficient for copepods by applying a correction factor $\left(\mathrm{k}_{\mathrm{p}}\right)$ derived from microzooplankton abundance and grazing coefficients, which are obtained in dilution experiments. Due to the lack of such simultaneous experiments, published maximum C-specific grazing coefficients for heterotrophic ciliates and dinoflagellates were used to correct copepod clearance rates. This, however, lead to unrealistically high copepod feeding rates on flagellates of 4.5 to $6.4 \mu \mathrm{g} \mathrm{C}$ female $\mathrm{d}^{-1} \mathrm{~d}^{-1}$, which considerably exceeded feeding rates on the much more abundant ciliates. Such severe overestimates may not only result from the application of maximum rates from the literature, but also from the inclusion of mixotrophic ciliates such as Laboea strobila in the potential grazer biomass, which were dominant microzooplankton and potentially displayed much lower feeding rates. This is supported by only small differences in the abundances of flagellates in control bottles between the natural and the enriched treatment, despite the large increase in ciliate biomass in the latter. Furthermore, Acartia spp. are known to switch their feeding mode from suspension to ambush feeding in response to a high availability of motile food (Kiørboe et al. 1996, Gismervik \& Andersen 1997). Due to the dominance of large ciliates in our study, suspension feeding and, thus, high clearance rates of females on flagellates are rather unlikely. Because of the ab- 
sence of evidence for a substantial grazing control of flagellates by microzooplankton and the observed preference of A. clausi for particles larger than $20 \mu \mathrm{m}$ (see below), clearance rates were not corrected.

\section{Prey selection patterns and daily ration}

Clearance rates of 0.5 to $3 \mathrm{ml}$ female $\mathrm{e}^{-1} \mathrm{~h}^{-1}$ for Acartia clausi feeding on various prey items are within the range observed for this species or its congeners in various natural ecosystems (Gifford \& Dagg 1991, Pérez et al. 1997, Rollwagen-Bollens \& Penry 2003). Higher clearance of ciliates in relation to co-occurring phytoplankton has been commonly reported in field studies and has often been attributed to motility, size and nutritional quality of microheterotrophs (e.g. Gifford \& Dagg 1991, White \& Roman 1992, Ohman \& Runge 1994, Nejstgaard et al. 1997, Vincent \& Hartman 2001, Broglio et al. 2004). In contrast, a higher clearance of small flagellates compared to larger protists has sometimes been observed and related to their high abundance and copepod prey preferences (e.g. RollwagenBollens \& Penry 2003, Vargas \& Gonzáles 2004).

Our results do not support a generally higher clearance for ciliates. In both treatments, ciliates were cleared at a similar rate to diatoms despite large differences in the biomass of both groups (Fig. 4). In contrast, dinoflagellates were cleared at a lower rate, although their availability was in the range of the biomass of ciliates. Because diatoms and ciliates dominated in the size range of 20 to 30 and $>30 \mu \mathrm{m}$, but dinoflagellates dominated in the 10 to $20 \mu \mathrm{m}$ range, which was also cleared at a significantly lower rate than the larger size classes, the observed differences were presumably size-based. The reduced clearance of cells $<20 \mu \mathrm{m}$ agrees well with results for Acartia spp. from other field studies (Rollwagen-Bollens \& Penry 2003, Katechakis et al. 2004) and size-dependent clearance of phytoplankton observed in the laboratory (Nival \& Nival 1976, Berggreen et al. 1988). Also, other studies indicate that large phytoplankton is cleared at the same rate as ciliates (Tiselius 1989, Ohman \& Runge 1994, Vargas \& Gonzáles 2004). This suggests that the often observed preference for ciliates might in fact reflect a size bias caused by the comparison of clearance rates of generally large microzooplankton with those of small phytoplankton or of chlorophyll $a$, which integrates over a wide range of particle sizes.

The more detailed taxonomic analysis of feeding by Acartia clausi, however, emphasized that conclusions regarding the clearance of taxonomic or size groups should be drawn with caution because highly different clearance rates and preferences for diverse prey are in fact integrated (see Fig. 5). Among the dinoflagellates, thecate dinoflagellates $<30 \mu \mathrm{m}$ were cleared at high rates and positively selected by females, whereas various other groups including the small, but abundant thecate dinoflagellates $<20 \mu \mathrm{m}$ were cleared at much lower rates. Similarly, the clearance rate for ciliates combined the strong preference for Laboea strobila with the apparent reluctance to feed on Strobiliidae and other ciliates. The diverse clearance rates of $A$. clausi for various particles indicates that the feeding response is complex rather than dependent on a single but still important factor such as prey size or abundance. Apart from motility and escape behaviour in ciliates (Broglio et al. 2001, Jakobsen et al. 2005), feeding mode (Jonsson \& Tiselius 1990), morphological cell features or distaste for specific algae (Wolfe 2000) may be responsible for shaping the feeding behaviour on various other groups.

In both treatments, ciliates were major food items and dominated the composition of the diet by more than $86 \%$, while other food particles contributed only a small fraction (Table 5). These values agree well with a high proportion of ciliates in copepod diets of more than $60 \%$ when they dominate the potential prey (Broglio et al. 2004, Calbet \& Saiz 2005). However, the daily ration obtained from feeding on ciliates is often low and rarely exceeds 20 to $30 \%$ of body weight (Calbet \& Saiz 2005). This obvious contrast shows that ciliates regularly dominate the diet under oligotrophic conditions when food availability is low or large parts of the phytoplankton production are unavailable for copepod consumption due to size constraints (Gifford \& Dagg 1991, Fessenden \& Cowles 1994). As a consequence, the ingested ration is often small because of low ciliate biomass. The daily consumption of Acartia clausi of 2.87 to $4.81 \mu \mathrm{g} \mathrm{C}$ female ${ }^{-1} \mathrm{~d}^{-1}$, which was

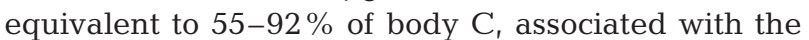
high dietary contribution of ciliates deviates considerably from the generally low rations obtained by copepods feeding under oligotrophic and post-bloom conditions, but falls well within the range of total rations recorded for this species (Pagano et al. 2003, Katechakis et al. 2004). This high daily ration likely resulted from the high ciliate biomass and the dominance of large species recorded in our study. Although an abundance of 4 to 6 cells ml ${ }^{-1}$ fits well with the range of 1 to 15 cells $\mathrm{ml}^{-1}$ observed for ciliates in various field studies, a biomass of more than $100 \mu \mathrm{g} \mathrm{C}^{-1}$ appears exceptionally high (compare to Calbet \& Saiz 2005).

Our attempt to study the feeding and egg production of Acartia clausi in response to the manipulation of the seston size structure failed regarding the intended selective increase of the biomass of larger protists by inverse fractionation. Instead, the concentration of all organism groups except flagellates, was similarly enhanced (Table 1). Nevertheless, the increase in the 
specific ingestion rates of females of $0.37 \mu \mathrm{g} \mathrm{C} \mu \mathrm{g} \mathrm{C} \mathrm{C}^{-1}$ $\mathrm{d}^{-1}$ in the enriched treatment compared to the natural treatment can be largely attributed to feeding on large ciliates which amounted to $0.36 \mu \mathrm{g} \mathrm{C} \mu \mathrm{g} \mathrm{C}^{-1} \mathrm{~d}^{-1}$ (Table 5). This likely reflects the strong preference of Acartia clausi for Laboea strobila associated with the dominance of this species and other large ciliates in the seston. The consumption of dinoflagellates, in contrast, remained similar in the 2 treatments although small changes in contribution of the various groups to the diet were observed. A decrease in the ingestion of small thecate dinoflagellates of 10 to $20 \mu \mathrm{m}$ was compensated by an increase in the clearance and ingestion of dinoflagellates $>30 \mu \mathrm{m}$ (Figs. $5 \& 6$ ). This might reflect an increase in the time females spent on ambush feeding in response to the increased availability of larger prey.

\section{Reproductive success, nutritional quality of diet and ciliates}

The egg production and egg hatching success of Acartia clausi were high during our study. The observed rates of 25 eggs female ${ }^{-1} \mathrm{~d}^{-1}$ are close to the maximum egg production of 25 to 33 eggs female ${ }^{-1} \mathrm{~d}^{-1}$ recorded for the North Sea during late spring (Halsband \& Hirche 2001) and indicate that females met with favourable conditions for high reproductive success. This is supported by the high gross efficiency of egg production of $39 \%$ for the natural treatment which is in the upper range reported for various copepods (Kiørboe et al. 1985, Straile 1997).

Estimates of the biochemical and mineral content of the bulk seston generally corroborate a high quality of the potential prey ingested by females. The low $\mathrm{C} / \mathrm{N}$ ratio of $<6$ and the composition of fatty acids with a high proportion of $\mathrm{C}_{18}$ - and $\mathrm{C}_{22}$-PUFAs are typical for the post-spring bloom conditions composed of flagellates, dinoflagellates and microzooplankton (Mayzaud et al. 1989, Pond et al. 1996). However, such bulk estimates inadequately characterize the diet of copepods when the dietary composition deviates from that of seston due to selective feeding. For instance, detritus and small flagellates not consumed by Acartia clausi were generally included in our biochemical analysis of total seston. In this respect, the fractionation of the seston in size fractions of <20, 20 to 48 and 48 to $100 \mu \mathrm{m}$ eliminated some of these under-utilized food sources and thus appeared more suitable in characterizing the nutritional quality of the ingested prey in general and of the preferred ciliates in particular.

The 20 to $48 \mu \mathrm{m}$ size fraction described the diet composition of females in the natural diet better than the bulk seston composition (Fig. 7). In addition to the elimination of flagellates and presumably a high amount of detritus, the contribution of small thecate dinoflagellates was reduced in favour of a higher contribution of ciliates compared to the bulk seston, similar to the diet of Acartia clausi. Laboea strobila, Strobiliidae and dinoflagellates contributed 58, 29 and $14 \%$ to the diet and 63,13 and $21 \%$ to the 20 to $48 \mu \mathrm{m}$ size fraction, but contributed 30,34 and $30 \%$ to the seston biomass. The mineral and biochemical characterization of seston revealed that the composition the 20 to $48 \mu \mathrm{m}$ size fraction and, thus, of the diet differed from bulk seston. The $\mathrm{C} / \mathrm{N}$ ratio of 4.4 indicated enrichment in $\mathrm{N}$ in comparison to the seston average of 5.5. The diet also included a disproportionately high amount of essential long-chain PUFA of $52 \%$ compared to the $40 \%$ of the total fatty acids in bulk seston. It was particularly rich in $\mathrm{C}_{18}$-PUFA, EPA, DHA and (n-3) fatty acids, which are favourable for high egg production and hatching success and cannot be synthesized de novo (Jónasdóttir et al. 1995, Broglio et al. 2003, Shin et al. 2003). Apparently, larger protists are particularly important sources of essential fatty acids in the nutrition of copepods.

The 48 to $100 \mu \mathrm{m}$ size fraction in the enriched treatment corresponded to the diet of Acartia clausi in this treatment (Fig. 7). While Laboea strobila, Strobiliidae and dinoflagellates respectively contributed 75 to 77 , 16 to 19 and $<5 \%$ to the size fraction and the diet, their share of about 30,37 and $22 \%$ in total seston was considerably different. Moreover, due to the dominance of Laboea strobila and Strobiliidae of more than $97 \%$ of total protists, the measurements for the mineral and biochemical content of the 48 to $100 \mu \mathrm{m}$ fraction characterize not only the diet of females in the enriched treatment, but can also be used to address the nutritional composition of large ciliates. These measurements showed that the volume-specific $\mathrm{C}$ and $\mathrm{N}$ contents of protists in the 48 to $100 \mu \mathrm{m}$ size fraction of 0.24

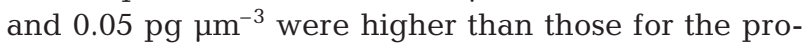
tists in the 20 to $48 \mu \mathrm{m}$ size range of 0.15 and $0.03 \mathrm{pg}$ $\mu^{-3}$. On the other hand, protists in the 48 to $100 \mu \mathrm{m}$ size fraction contained considerably less PUFA (39\%) than protists in the 20 to $48 \mu \mathrm{m}$ size range (52\%) at a similar volume-specific fatty acid content of 33 to $35 \mathrm{fg}$ $\mu \mathrm{m}^{-3}$. This indicates that ciliates apparently provided a disproportionately high amount of $\mathrm{N}$ to females, while the dinoflagellates, which were more abundant in the 20 to $48 \mu \mathrm{m}$ fraction, were the more important source for essential fatty acids. Hence, the biochemical content of ciliates does not always appear to be superior compared to other prey, as has been concluded in the literature (e.g. Stoecker \& Capuzzo 1990, Sanders \& Wickham 1993, but see Broglio et al. 2003).

The biochemical measurements also revealed substantial compositional differences in fatty acids 
between the bulk seston and the ciliates dominating the 48 to $100 \mu \mathrm{m}$ fraction. The ciliates were characterized by a higher proportion of 14:0, 16:0, 18:1(n-7) and EPA, but a lower proportion of particularly polyunsaturated fatty acids such as 18:3(n-3), 18:4(n-3) and DHA. This further suggests that dinoflagellates were in fact the major source of these important $\mathrm{C}_{18}$-PUFAs and DHA, which agrees well with measurements of their composition in the laboratory (Broglio et al. 2003, Dalsgaard et al. 2003, Tang \& Taal 2005). In contrast, comparatively little is known of the composition of marine ciliates. The dominance of EPA and the lack of major quantities of $\mathrm{C}_{18}$-PUFAs in Laboea strobila and the Strobiliidae contrast with the high proportions of $\mathrm{C}_{18}$-PUFA recently determined for Mesodinium pulex or Strombidium sulcatum (Broglio et al. 2003, Klein Breteler et al. 2004), but agree well with composition of a natural assemblage dominated by tintinnids in the Mediterranean (Claustre et al. 1988/89). Arendt et al. (2005) also observed higher levels of EPA following the spring bloom, which coincided with the occurrence of L. strobila (S. Jónasdóttir pers. comm.). The fatty acid composition of ciliates, however, can be quite variable and is largely determined by their food because of an apparent inability to modify dietary sources (Broglio et al. 2003, Klein Breteler et al. 2004). In this respect, the origin of EPA in ciliates is interesting. Trophic marker studies identified diatoms or Eustigmatophyceae as major pelagic sources of this fatty acid (Dalsgaard et al. 2003). However, these were rare during our investigation. Whether the specific fatty acid composition of the ciliates reflects a long-term feeding history on specific phytoplankton or alternatively, a potentially mixotrophic physiology known for the dominant oligotrich Laboea strobila remains to be elucidated.

\section{CONCLUSIONS}

Our evidence for high egg production of Acartia clausi supported largely by oligotrich ciliates contrasts considerably with the general idea of a minor role for ciliates in egg production and recruitment of copepods. From their analysis of seasonal variation in egg production of several copepod species in relation to seston composition, Kiørboe \& Nielsen (1994) concluded that ciliate biomass is generally too low to contribute significantly to annual egg production. This is corroborated by the fact that the daily ration of copepods feeding on ciliates is generally minor (Calbet \& Saiz 2005). In this respect, our results appear to reflect a small-scale event during a biomass peak of ciliates, which is well known to occur irregularly and unpredictably in comparison to phytoplankton blooms (e.g. Smetacek 1981, Nielsen \& Kiørboe 1994). However, biomass peaks of large oligotrich ciliates like Laboea spp. have been frequently observed following the spring diatom bloom (Smetacek 1981, Nielsen \& Kiørboe 1994, Nejstgaard et al. 2001), which suggests that such events are a regular phenomenon in the seasonal succession of the pelagic system. Moreover, in comparison to other small coastal copepod species such as Temora longicornis or Pseudocalanus spp., the seasonal peak in egg production of A. clausi or A. tonsa is delayed and occurs in May to June rather than April to May (Kiørboe \& Nielsen 1994, Halsband \& Hirche 2001). This suggests that spring recruitment of $A$. clausi may be related to the successional occurrence of large ciliates. The strength of this link and the potential correlation of the succession of diatoms and large ciliates as indicated by the specific fatty acid pattern require further investigation. Nevertheless, high daily rations of copepods feeding on microzooplankton appear to be primarily realized in the presence of large ciliates rather than due to an exceptionally high abundance (Gifford \& Dagg 1991, Ohman \& Runge 1994, Liu et al. 2005) making them particularly important for the recruitment of marine zooplankton populations.

Acknowledgements. The study was funded by the German Federal Ministry for Education and Research within the GLOBEC GERMANY project (03F0418C). We thank the crew and scientific parties of the RV 'Heincke' for excellent support during the field phase. We also thank C. v. Waldthausen and B. Niehoff for C/N ratio measurements, and M. Koski and J. T. Turner for valuable comments on an earlier version of the manuscript.

\section{LITERATURE CITED}

Arendt KE, Jónasdóttir SH, Hansen PJ, Gärtner S (2005) Effects of dietary fatty acids on the reproductive success of the calanoid copepod Temora longicornis. Mar Biol 146: 513-530

Bergreen U, Hansen B, Kiørboe T (1988) Food size spectra, ingestion and growth of the copepod Acartia tonsa during development: implications for determination of copepod production. Mar Biol 99:341-352

Berk SG, Brownlee DC, Heinle DR, Kling HJ, Colwell RR (1977) Ciliates as food source for marine planktonic copepods. Microb Ecol 4:27-40

Broglio E, Johansson M, Jonsson PR (2001) Trophic interaction between copepods and ciliates: effects of prey swimming behaviour on predation risk. Mar Ecol Prog Ser 220:179-186

Broglio E, Jónasdóttir SH, Calbet A, Jakobsen HH, Saiz E (2003) Effect of heterotrophic versus autotrophic food on feeding and reproduction of the calanoid copepod Acartia tonsa: relationship with prey fatty acid composition. Aquat Microb Ecol 31:267-278

Broglio E, Saiz E, Calbet A, Trepat I, Alcaraz M (2004) Trophic impact and prey selection by crustacean zooplankton on the microbial communities of an oligotrophic coastal area (NW Mediterranean Sea). Aquat Microb Ecol 35:65-78

Calbet A, Saiz E (2005) The ciliate-copepod link in marine 
ecosystems. Aquat Microb Ecol 38:157-167

Chesson J (1978) Measuring preference in selective predation. Ecology 59:211-215

Chesson J (1983) The estimation and analysis of preference and its relationship to foraging models. Ecology 64:1297-1304

Claustre H, Marty JC, Cassiani L, Dagaut J (1988/89) Fatty acid dynamics in phytoplankton and microzooplankton communities during a spring bloom in the coastal Ligurian Sea: ecological implications. Mar Microb Food Webs 3: 51-66

Dalsgaard J, St John M, Kattner G, Müller-Navarra D, Hagen W (2003) Fatty acid trophic markers in the pelagic environment. Adv Mar Biol 46:225-340

Dam HG, Peterson WT, Bellatoni DC (1994) Seasonal feeding and fecundity of the calanoid copepod Acartia tonsa in Long Island Sound: Is omnivory important to egg production? Hydrobiologia 292-293:191-199

Ederington MC, McManus GB, Harvey HR (1995) Trophic transfer of fatty acids, sterols, and a triterpenoid alcohol between bacteria, a ciliate, and the copepod Acartia tonsa. Limnol Oceanogr 40:860-867

Fessenden L, Cowles TJ (1994) Copepod predation on phagotrophic ciliates in Oregon coastal waters. Mar Ecol Prog Ser 107:103-111

Folch J, Lees M, Sloane-Stanley GH (1957) A simple method for isolation and purification of total lipids from animal tissues. J Biol Chem 226:497-509

Frost BW (1972) Effects of size and concentration of food particles on the feeding behaviour of the marine planktonic copepod Calanus pacificus. Limnol Oceanogr 17:805-815

Gifford DJ (1985) Laboratory culture of marine planktonic oligotrichs (Ciliophora: Oligotrichida). Mar Ecol Prog Ser 23:257-267

Gifford DN, Dagg MJ (1991) The microzooplankton-mesozooplankton link: consumption of planktonic protozoa by the calanoid copepods Acartia tonsa Dana and Neocalanus plumchrus Murukawa. Mar Microb Food Webs 5:161-177

- Gismervik I, Andersen T (1997) Prey switching by Acartia clausi: experimental evidence and implications of intraguild predation assessed by a model. Mar Ecol Prog Ser 157:247-259

> Halsband C, Hirche HJ (2001) Reproductive cycles of dominant calanoid copepods in the North Sea. Mar Ecol Prog Ser 209:219-229

Jakobsen HH, Halvorsen E, Hansen BW, Visser AW (2005) Effects of prey motility and concentration on feeding in Acartia tonsa and Temora longicornis: the importance of feeding modes. J Plankton Res 27:775-785

> Jónasdóttir SH, Fields D, Pantoja S (1995) Copepod egg production in Long Island Sound, USA, as a function of the chemical composition of seston. Mar Ecol Prog Ser 119: 87-98

Jonsson PR, Tiselius P (1990) Feeding behaviour, prey detection and capture efficiency of the copepod Acartia tonsa feeding on planktonic ciliates. Mar Ecol Prog Ser 60:35-44

Katechakis A, Stibor H, Sommer U, Hansen T (2004) Feeding selectivities and food niche separation of Acartia clausi, Penilia avirostris (Crustacea), and Doliolum denticulatum (Thaliaceae) in Blanes Bay (Catalan Sea, NW Mediterranean). J Plankton Res 26:589-603

Kattner G, Fricke HSG (1986) Simple gas-liquid chromatography method for simultaneous determination of fatty acids and alcohols in wax esters of marine organisms. J Chromatogr 361:263-268

Kiørboe T, Nielsen TG (1994) Regulation of zooplankton biomass and production in a temperate coastal ecosystem.
1. Copepods. Limnol Oceanogr 39:493-507

Kiørboe T, Møhlenberg F, Hamburger K (1985) Bioenergetics of the planktonic copepod Acartia tonsa: relation between feeding, egg production and respiration, and composition of specific dynamic action. Mar Ecol Prog Ser 26:85-97

- Kiørboe T, Saiz E, Viitasalo M (1996) Prey switching behaviour in the planktonic copepod Acartia tonsa. Mar Ecol Prog Ser 143:65-75

Klein Breteler WCM, Schogt N, Baas M, Schouten S, Kraay GW (1999) Trophic upgrading of food quality by protozoans enhancing copepod growth: role of essential lipids. Mar Biol 135:191-198

Klein Breteler WCM, Koski M, Rampen S (2004) Role of essential lipids in copepod nutrition: no evidence for trophic upgrading of food quality by a marine ciliate. Mar Ecol Prog Ser 274:199-208

Leakey RJG, Burkill PH, Sleigh MA (1994) A comparison of fixatives for the estimation of abundance and biovolume of planktonic ciliate populations. J Plankton Res 16:375-389

Levinsen H, Turner JT, Nielsen TG, Hansen BW (2000) On the trophic coupling between protists and copepods in artic marine ecosystems. Mar Ecol Prog Ser 204:65-77

Liu H, Dagg MJ, Wu CJ, Chiang KP (2005) Mesozooplankton consumption of microplankton in the Mississippi River Plume, with special emphasis on planktonic ciliates. Mar Ecol Prog Ser 286:133-144

Mayzaud P, Chanut JP, Ackman RG (1989) Seasonal changes of the biochemical composition of marine particulate matter with special reference to fatty acids and sterols. Mar Ecol Prog Ser 56:189-204

Menden-Deuer S, Lessard EJ (2000) Carbon to volume relationships for dinoflagellates, diatoms, and other protist plankton. Limnol Oceanogr 45:569-579

> Merrell JR, Stoecker DK (1998) Differential grazing on protozoan microplankton by developmental stages of the calanoid copepod Eurytemora affinis Poppe. J Plankton Res 20:289-304

Montagnes DJS, Berges JA, Harrison PJ, Taylor FJR (1994) Estimating carbon, nitrogen, protein, and chlorophyll a from volume in marine phytoplankton. Limnol Oceanogr 39:1044-1060

Nejstgaard JC, Gismervik I, Solberg PT (1997) Feeding and reproduction by Calanus finmarchicus, and microzooplankton grazing during mesocosm blooms of diatoms and the coccolithophore Emiliana huxleyi. Mar Ecol Prog Ser 147:197-217

Nejstgaard JC, Huygum BH, Naustvoll LJ, Båmstedt U (2001) Zooplankton growth, diet and reproductive success compared in simultaneous diatom- and flagellate-microzooplankton-dominated plankton blooms. Mar Ecol Prog Ser 221:77-91

Nielsen TG, Kiørboe T (1994) Regulation of zooplankton biomass and production in a temperate coastal ecosystem. 2. Ciliates. Limnol Oceanogr 39:508-519

Nival P, Nival S (1976) Particle retention efficiencies of an herbivorous copepod Acartia clausi (adult and copepod stages): effects on grazing. Limnol Oceanogr 21:24-36

Ohman MD, Runge JA (1994) Sustained fecundity when phytoplankton resources are in short supply: omnivory by Calanus finmarchicus in the Gulf of St. Lawrence. Limnol Oceanogr 39:21-26

Pagano M, Kouassi E, Saint-Jean L, Arfi R, Bouvy M (2003) Feeding of Acartia clausi and Pseudodiaptomus hessei (Copepoda: Calanoida) on natural particles in a tropical lagoon (Ebié, Côte d'Ivoire). Estuar Coast Shelf Sci 56: 433-445

Pérez MT, Dolan JR, Fukai E (1997) Planktonic oligotrich 
ciliates in the NW Mediterranean: growth rates and consumption by copepods. Mar Ecol Prog Ser 155:89-101

Pond D, Harris R, Head R, Harbour D (1996) Environmental and nutritional factors determining seasonal variability in the fecundity and egg viability of Calanus helgolandicus in coastal waters off Plymouth, UK. Mar Ecol Prog Ser 143:45-63

Putt M, Stoecker DK (1989) An experimentally determined carbon:volume ratio for marine 'oligotrichous' ciliates from estuarine and coastal waters. Limnol Oceanogr 34: 1097-1103

Rollwagen-Bollens GC, Penry DL (2003) Feeding dynamics of Acartia spp. copepods in a large, temperate estuary (San Francisco Bay, CA). Mar Ecol Prog Ser 257:139-158

Sanders RW, Wickham SA (1993) Planktonic protozoa and metazoan: predation, food quality and population control. Mar Microb Food Webs 7:197-223

Sherr EB, Sherr BF (1988) Role of microbes in pelagic food webs: a revised concept. Limnol Oceanogr 33:1225-1227

Shin K, Jang MC, Jang PK, Ju SJ, Lee TK, Chang M (2003) Influence of food quality on egg production and viability of the marine planktonic copepod Acartia omorii. Prog Oceanogr 57:265-277

Smetacek V (1981) The annual cycle of protozooplankton in the Kiel Bight. Mar Biol 63:1-11

Sokal RR, Rohlf FJ (1995) Biometry. Freeman, New York

> Stoecker DK, Capuzzo JM (1990) Predation on protozoa: its importance to zooplankton. J Plankton Res 12:891-908

Stoecker DK, Egloff DA (1987) Predation by Acartia tonsa Dana on planktonic ciliates and rotifers. J Exp Mar Biol Ecol 110:53-68

Stoecker DK, Gifford DJ, Putt M (1994) Preservation of marine planktonic ciliates: losses and cell shrinkage during fixation. Mar Ecol Prog Ser 110:293-299

Straile D (1997) Gross growth efficiencies of protozoan and

Editorial responsibility: Urania Christaki,

Wimereux, France metazoan zooplankton and their dependence on food concentration, predator-prey weight ratio, and taxonomic group. Limnol Oceanogr 42:1375-1385

Tang KW, Taal M (2005) Trophic modification of food quality by heterotrophic protists: species-specific effects on copepod egg production and egg hatching. J Exp Mar Biol Ecol 318:85-98

Tiselius P (1989) Contribution of aloricate ciliates to the diet of Acartia clausi and Centropages hamatus in coastal waters. Mar Ecol Prog Ser 56:49-56

Turner JT, Anderson DM (1983) Zooplankton grazing during dinoflagellate blooms in a Cape Cod embayment, with observations of predation upon tintinnids by copepods. PSZN I Mar Ecol 4:359-374

Utermöhl H (1958) Zur Vervollkommnung der qualitativen Phytoplankton-Methodik. Mitt Int Verein Theor Angew Limnol 9:1-38

Uye SI (1982) Length-weight relationships of important zooplankton from the Inland Sea of Japan. J Oceanogr Soc Jpn 38:149-158

Vargas CA, González HE (2004) Plankton community structure and carbon cycling in a coastal upwelling system. I. Bacteria, microprotozoans and phytoplankton in the diet of copepods and appendicularians. Aquat Microb Ecol 34:151-164

Vincent D, Hartman HJ (2001) Contribution of ciliated microprotozoans and dinoflagellates to the diet of 3 copepod species in the Bay of Biscay. Hydrobiologia 443:193-204

White JR, Roman MR (1992) Egg production by the calanoid copepod Acartia tonsa in the mesohaline Chesapeake Bay: the importance of food resources and temperature. Mar Ecol Prog Ser 86:239-249

Wolfe GV (2000) The chemical defense ecology of marine unicellular plankton: constraints, mechanism, and impacts. Biol Bull 198:225-244

Submitted: November 10, 2006; Accepted: November 26, 2007 Proofs received from author(s): February 23, 2008 